\title{
Characterization of Gas-Solid Reactions using In Situ Powder X-ray Diffraction
}

\author{
Kasper T. Møller, ${ }^{[\mathrm{a}]}$ Bjarne R. S. Hansen, ${ }^{[\mathrm{a}]}$ Ann-Christin Dippel, ${ }^{[\mathrm{b}]}$ \\ Jens-Erik Jørgensen, ${ }^{[a]}$ and Torben R. Jensen*[a]
}

Keywords: In situ powder X-ray diffraction; Gas-solid reactions; Reactive hydride composites; Hydrogen storage

Abstract. X-ray diffraction is a superior technique for structural characterization of crystalline matter. Here we review the use of in situ powder X-ray diffraction (PXD) mainly for real-time studies of solidgas reactions, data analysis and the extraction of valuable knowledge of structural, chemical and physical properties. Furthermore, the diffraction data may also provide knowledge on reaction mechanisms, kinetics and thermodynamic properties. Thus, in situ PXD simultaneously provides properties as a function of pressure, temperature and/ or time at different length scales, i.e. nanoscale structural data and bulk sample properties. Initially, a brief description of experimental and methodological details is provided, followed by a variety of examples of different designs of experiments and methods of data analysis. Additionally, it is discussed how a range of physical properties can be accessed by diffraction techniques, e.g. crystallite size. The aim of this review is to provide new inspiration for utilization of in situ PXD for characterization of a wide range of properties beyond the scope of crystal structure solution.

\section{Introduction}

The continuously growing interest in nanometer-scale structural characterization within chemistry and materials science provides strong incentives for the further development of $\mathrm{X}$ ray diffraction techniques. ${ }^{[1]}$ This is strongly accelerated by access to intense, well-collimated photon beams from synchrotron X-ray sources, which has also allowed development of in situ diffraction techniques for a number of purposes. Synthesis of new materials is an essential aspect of materials science and these are often powders or composites. Novel materials with new functional properties often form the backbone in emerging energy technologies. In situ synchrotron radiation powder Xray diffraction (SR-PXD) is essential for characterization of structural, chemical and physical properties of crystalline solids under varying pressures and temperatures as well as polymorphic transformations. Chemical reactions between crystalline matter and other solids, liquids or gasses may also be explored regarding the detailed mechanism and the kinetics of reaction.

The investigation of solid materials properties and solid-solid reactions at varying temperature and at ambient pressure appears to be among the most frequent studies within materials science using in situ SR-PXD. Recently, significant progress

\footnotetext{
* Prof. Dr. T. R. Jensen E-Mail: trj@chem.au.dk

[a] Center for Materials Crystallography

iNANO and Chemistry Department

University of Aarhus

Langelandsgade 140

8000 Aarhus C, Denmark

[b] Deutsches Elektronen-Synchrotron DESY

Notkestrasse 85

22607 Hamburg, Germany
}

within development of new advanced sample holders which allow in situ and in operando investigations of batteries while they are charged and discharged at a synchrotron beam line has been developed, ${ }^{[2]}$ providing e.g. new information on lithium insertion reactions in lithium ion batteries ${ }^{[3]}$ and on reaction mechanisms in conversion type cathodes. ${ }^{[4]}$

Solid-gas reactions were initially investigated in order to explore reaction mechanisms within heterogeneous catalysis. ${ }^{[5]}$ The first sample holder which allows a gas-flow through the sample was based on open-ended quartz $\left(\mathrm{SiO}_{2}\right)$ capillaries. Changes in the solid catalyst may be probed as a function of gas composition and temperature. A narrow particle size distribution is needed in order to prevent the sample from blocking the gas flow, i.e. the sample often needs to be sieved, and glass wool plugs are needed in order to hold the powder in place. Solid-gas reactions may also be investigated in dosing mode using capillaries with one closed end. ${ }^{[6,7]}$ This technique has been further developed by gluing a metal ferrule to a capillary, which may allow a $0.5 \mathrm{~mm}$ quartz capillary to be used at gas pressures up to ca. 100 bar and provides minimal X-ray absorption and good resolution due to the small sample size. ${ }^{[8]}$ Graphite, vespel and graphite/vespel ferrules are more commonly used when mounting a thin quartz capillary, however lower pressures $(<25$ bar) can be obtained. The gas dosing technique is also very useful for investigation of physisorption of gasses in nano-porous crystalline scaffolds. ${ }^{[9]}$ In situ SRPXD has proven superior to any other technique as it simultaneously probes the exact host-guest interactions, provides information on the amount of gas physisorbed as a function of pressure and temperature and in some cases simultaneously thermodynamic data such as the isosteric enthalpy of adsorption. ${ }^{[10]}$ 
The use of single crystalline sapphire $\left(\mathrm{Al}_{2} \mathrm{O}_{3}\right)$ capillaries has proven successful as it, compared to quartz, has larger tensile strength, is more inert towards e.g. molten hydrides, and allows higher working pressures and more abrupt changes of pressure. ${ }^{[3]}$ This is desirable for investigation of fast solid-gas reactions, e.g. for reversible solid state hydrogen storage. Hydrogen release and uptake reactions are often associated with considerable change in unit cell volume, often around $20 \%$ for interstitial metallic hydrides, ${ }^{[11]}$ or significant changes of structural symmetry, e.g. ionic hydrides often change from ionic to metallic form. Complex metal hydrides with covalently bonded hydrogen change structure and composition via several intermediate compounds. ${ }^{[12-14]}$ Thus, even though hydrogen has the lowest X-ray scattering power of any element, the effects of hydrogen absorption and desorption are easily observable by PXD. ${ }^{[15]}$

Solid-liquid reactions at supercritical conditions have also attracted much attention recently. The solid-liquid systems can be contained in an open-ended capillary, e.g. sapphire, at elevated temperatures and may allow for a flow of reactants through the sample holder also at super critical conditions. ${ }^{[16-18]}$

Solid-liquid reactions at hydrothermal conditions, using water as a solvent, have also been investigated, often at 100 $<T<200{ }^{\circ} \mathrm{C}$, using quartz capillaries with one closed end as sample holder. A back pressure of inert gas larger than the vapour pressure of water at the maximum reaction temperature is needed to prevent the solid-liquid suspension from boiling. ${ }^{[19-22]}$

Fast solid-liquid reactions may also be investigated in capillaries with one end closed. This experimental approach allows for 'in situ mixing of solids and liquids', e.g. for investigation of fast hydrolysis reactions. For example, a quartz glass capillary $(0.7 \mathrm{~mm}$ O.D.) placed in a vertical position was loaded with a slightly compacted powder of $\alpha-\mathrm{CaSO}_{4} \cdot 0.5 \mathrm{H}_{2} \mathrm{O}$ and

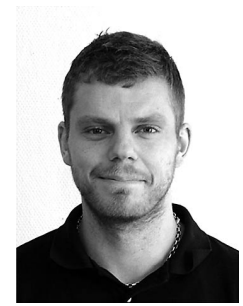

Kasper T. Mфller received his BSc in Chemistry \& Technology from Aarhus University, Denmark in 2012. He is currently working as a PhD student in the group of Associate Prof. Torben R. Jensen, Aarhus University and his work is financed by the Danish council for strategic research via the project HyFillFast, the Center for Materials Crystallography, CMC, and the interdisciplinary Nanoscience Center, iNANO, at Aarhus University. His current research interests focuses on the synthesis and characterization of metal borohydrides and bimetallic combinations of these. Furthermore, he is exploring possible reactions of metal-hydrides/borohydrides at pressures which match current high-pressure gas tanks for vehicles.

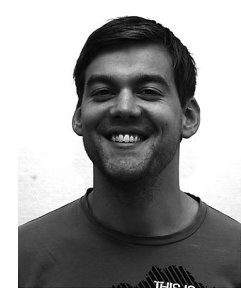

Bjarne R. S. Hansen studied Chemistry \& Technology at Aarhus University and Aarhus School of Engineering from 20072010, and later received a master's degree in Process-technology from Aarhus University. In 2012 he initiated Phd education. at the Center for Materials Crystallography $(C M C)$ and interdisciplinary Nano science center (iNano) in Aarhus, where the main focus is to investigate materials for hydrogen storage. Bjarne has since 2012 been a member of the steering group for the Hydrogen and Fuel Cell Academy, Denmark. His research topics include reactive hydride composites, eutectic melting systems, nanoconfinement, synthesis and materials science.

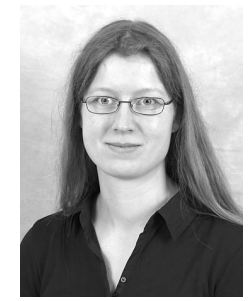

Ann-Christin Dippel graduated from her masters studies in materials science from RWTH Aachen University in 2004. She did her doctoral studies at the Institute for Materials in Electrical Engineering at RWTH Aachen University and earned her Doctor in Engineering in 2010. Since then, she has worked as beamline scientist at beamline P02.1 for high resolution and high energy powder diffraction at the synchrotron light source PETRA III at DESY in Hamburg. Her main research activities are the study of nanomaterials such as thin films and nanoparticles with respect to their microstructure and functional properties. In particular, she focuses on tracking the structural transformations on atomic scale in situ during synthesis of the materials under realistic conditions in real time.

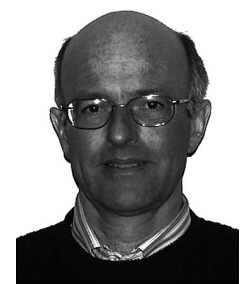

Jens-Erik Jorgensen was born in Svendborg, Denmark in 1955 and received his Ph.D. in chemistry from Aarhus University in 1984. After a postdoctoral position at Argonne National Laboratory, USA he held positions at the Hahn-Meitner Institute in Berlin and at the Neutron Research Laboratory in Studsvik, Sweden and returned to Aarhus University in 1988. His research interests are solid-state chemistry and X-ray and neutron diffraction with special emphasis on studies of superconducting, magnetic and hydrogen storage materials as well as diffraction studies of materials under high-pressure/low temperature conditions.

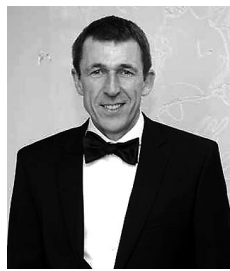

Torben R. Jensen received his PhD degree from Odense University, SDU, 1999, in materials chemistry. He did postdoctoral research at Condensed Matter Physics and Chemistry Department, Ris $\phi$ National Laboratory. He became an Assistant Professor (2000) and Research Associate Professor (2002) at the Interdisciplinary Nanoscience Center (iNANO) and Department of Chemistry, Aarhus University. He was awarded a Steno research stipend (2002) by the Danish research council and a Carlsberg research stipend (2005) by the Carlsberg Foundation. In 2014, he was awarded the Doctor of science degree (dr. scient.) by the Faculty of Science and Technology, Aarhus University for his research efforts within new inorganic nanomaterials for hydrogen storage. His research interests are focused on synthesis, structural, physical and chemical properties of inorganic materials and utilisation of synchrotron X-ray radiation for materials characterization, which is the topic for his 180 scientific publications. 
then water was introduced in the capillary so that the meniscus was approx. $2 \mathrm{~mm}$ from the dry sample. After measurement of a few diffraction patterns at the desired temperature, the gas pressure in the capillary was raised to $p\left(\mathrm{~N}_{2}\right) \approx 13$ bar, which brings water in contact with the dry sample in situ during data acquisition, and the hydration reaction starts. ${ }^{[19]}$ This technique allows the study of very fast chemical reactions e.g. the hydration of cements. ${ }^{[20,21]}$

Here we review the use of in situ SR-PXD for investigation of synthesis mechanisms and characterisation within materials science. A prominent use of the technique is for structural investigation of new materials. Furthermore, chemical properties such as reaction mechanisms, identification of intermediate compounds and sample composition as a function of time and temperature are also observable. Physical properties such as kinetics, thermodynamics along with changes in crystallite size etc. may also be accessible from SR-PXD data. However, SRPXD also suffers limitations. Amorphous materials can hardly be identified by X-ray diffraction and may only appear as broad humps in the scattered background as for $\mathrm{Li}_{2} \mathrm{~B}_{12} \mathrm{H}_{12}$ or clearly visible by solid state NMR as for $\mathrm{LiBH}_{4}$ in a sample of $\mathrm{LiBH}_{4}-\mathrm{Y}\left(\mathrm{BH}_{4}\right)_{3} .{ }^{[23,24]}$ Structures containing both light and heavy elements are usually challenging to investigate as observed for a new compound, $\mathrm{LiCe}\left(\mathrm{BH}_{4}\right)_{3} \mathrm{Cl}$, discussed later in this review. ${ }^{[25]}$ In such cases supplementary techniques e.g. powder neutron diffraction, spectroscopy or theoretical modelling are required to obtain full understanding of the crystal structure.

The aim of this review is to provide new inspiration for the utilisation of the very versatile technique in situ powder X-ray diffraction.

\section{Experimental and Methodological Details}

New sample environments are developed to take best advantage of X-ray diffraction techniques and well- collimated intense X-ray beams from synchrotron sources for investigating solid-gas and solid-solid reactions. ${ }^{[8]}$

Thin-walled single-crystal sapphire $\left(\mathrm{Al}_{2} \mathrm{O}_{3}\right)$ capillaries ${ }^{[26]}$ are often used owing to high tensile strength. For example, the calculated and measured burst pressures for a 1.09 (O.D.) $\times 0.79$ (I.D.) $\mathrm{mm}$ capillary are 880 and 900 bar, respectively. ${ }^{[8]}$

Additionally, very high quality SR-PXD data are obtained using thin-walled sapphire or quartz glass capillaries, which allows Rietveld refinement and extraction of detailed structural data. Glass capillaries, e.g. quartz, give a broad background in the diffraction patterns due to the structure factor of the amorphous material that extends out to several inverse angstroms in reciprocal space. Borosilicate and special glass capillaries result in lower background than quartz; however the maximum operating temperature is lowered to approx. $700{ }^{\circ} \mathrm{C}$ and approx. $500{ }^{\circ} \mathrm{C}$, respectively. Sapphire capillaries produce single-crystal reflections that may have orders of magnitude higher intensity than the diffracted intensity in the powder diffraction rings measured by the $2 \mathrm{D}$ detector and may overexpose the detector. These diffraction spots may be minimized by rotating the sample cell a few degrees in $\phi,{ }^{[8]}$ and subsequently they must be masked out during data integration, e.g. using software like Fit2D or PyFAI. ${ }^{[27-29]}$ Alternatively, intense and unwanted diffraction may also be masked by placing lead in front of the detector. These programs are used to convert the area detector frames (image files, binary format) to powder diffraction patterns, $I(2 \theta)$ (ASCII format). The use of an 2D area detectors gives several advantages, such as: $(i)$ integration of the intensity from the complete X-ray diffraction cone may reduce or eliminate preferred orientation effects, (ii) improvement of the 'powder average' for the obtained PXD data, e.g. in case a chemical reaction product is larger crystals that give 'spotty' diffraction rings, (iii) visual inspection of the data and identification of diffraction from other sources than the sample, e.g. diffraction rings with a centre different from the direct X-ray beam or as diffraction spots located away from the diffraction rings from the sample. ${ }^{[30]}$

The sample cell, shown in Figure 1, is heated by a resistive heating element (tungsten filament) or a stream of hot air. The temperature is measured by a thermocouple, placed inside the sapphire capillary ca. $1 \mathrm{~mm}$ from the sample and connected to a programmable temperature controller. The sample cell can be operated in the temperature range $\mathrm{RT}<T<$ approx. $700{ }^{\circ} \mathrm{C}$ with the described setup. Alternatively, temperatures as high as approx. $1000^{\circ} \mathrm{C}$ can be reached if the filament is wound directly around the sapphire capillary or by using two filaments. ${ }^{[31-33]}$

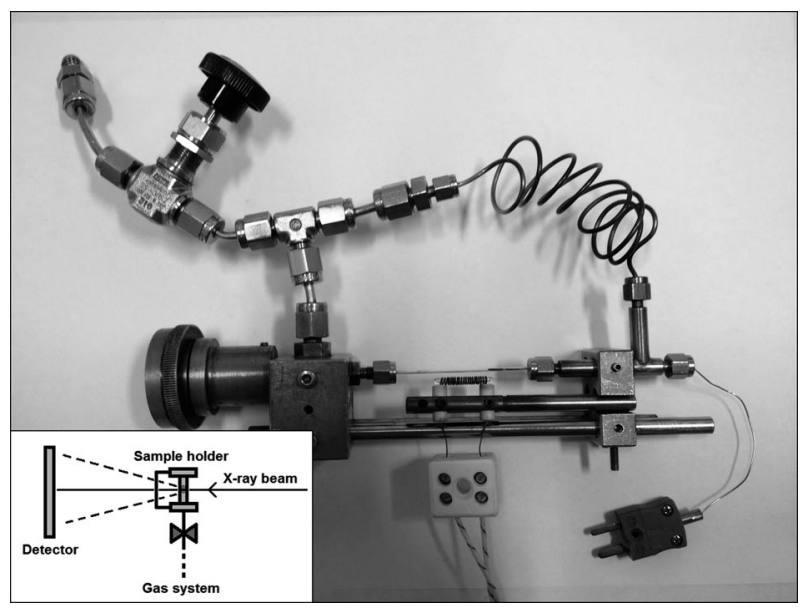

Figure 1. The in situ sample cell and a schematic drawing of the setup.

Alternatively, a temperature calibration material with wellknown phase changes or a large thermal expansion coefficient (e.g. $\mathrm{NaCl}$ or $\mathrm{Ag}$ ) is appropriate for determining a calibration curve for the real sample temperature. Initially, the temperature calibration material is heated within the desired temperature range. Sequential Rietveld refinement is then applied to determine the change in lattice parameters. Another advantageous tool is Parametric Rietveld refinement that improves the reliability of the temperature standard material and has benefits over sequential Rietveld refinement by reducing the overall uncertainty. In contrast to sequential Rietveld refinement, parametric refinement treats the whole data set at once and can 
describe structural parameters by variables and functions that describe their evolution throughout the entire data set. ${ }^{[34]}$

Another major advantage of the sample cell is that the sample is pressurized simultaneously from both ends, which allows fast change of pressure over more than five orders of magnitude, e.g. from 200 bar to $<1$ mbar within $\sim 10$ s, without destroying the sample. This ability combined with short data acquisition time of the PXD pattern provides excellent time resolution of gas absorption and desorption reactions. For practical application the lower gas pressure is limited by the performance of the vacuum pump as well as the diameter of the tubing. ${ }^{[35,36]}$ The upper limitation is the available gas pressure in the gas supply bottle attached to the gas control system. Furthermore, the gas atmosphere may be changed during the experiment, e.g. from argon to hydrogen or other gasses e.g. $\mathrm{O}_{2}, \mathrm{CO}_{2}$, or $\mathrm{N}_{2}$. Note that there may be a significant pressure change in long gas supply lines, therefore a pressure measurement close to the sample is important. ${ }^{[36]}$

There are several advantages of utilisation of high energy synchrotron $\mathrm{X}$-ray radiation $>30 \mathrm{keV}(<0.41 \AA)$. The penetration power increases with increasing photon energy, which facilitates the use of thicker sample containers, e.g. for investigations at elevated pressures. There is also lower air scattering of the diffracted beams that allows for larger sample-to-detector distances without significant loss in signal intensity. At the same time, a larger sample-to-detector distance provides more space for advanced sample environments, simultaneous measurements with more than one technique, and may further protect (expensive) detectors. Nevertheless, a protective screen is compulsory. High energy X-rays also compress the powder pattern to a smaller $2 \theta$ range, which is advantageous. This allows for a smaller aperture in the screen for the diffracted beam to improve safety. The aperture limits the $2 \theta$ range observable hence the high-energy X-rays allow for a large dspacing range to be observed in a small angular range providing a safer experimental setup.

\section{Results and Discussion}

Numerous examples of different types of in situ SR-PXD experiments and approaches for data analysis are provided in this section. The aim is to illustrate the perspectives and the diversity of information that can be extracted from in situ SRPXD data.

\section{1) Ab Initio Structural Investigations}

Mechanochemical synthesis combined with characterization using variable temperature in situ synchrotron radiation powder X-ray diffraction (VT SR-PXD) has successfully been used as an experimental screening approach in order to discover novel materials. Simultaneously, unique information about material composition, structure and properties such as chemical reactions and thermal decomposition pathways have been provided. ${ }^{[37-39]}$ The efficiency and versatility of this approach was illustrated by studying a series of novel cadmium-based metal borohydrides. ${ }^{[40]}$ Within this study, the existence of alkali- metal $(\mathrm{M}=\mathrm{Li}, \mathrm{Na}$ or $\mathrm{K})$ cadmium borohydrides was screened by mechanochemical treatment i.e. ball milling of the compositions $\mathrm{MBH}_{4}-\mathrm{CdCl}_{2}(1: 1,2: 1,3: 1$, and 4:1). The resulting materials were characterized by time-resolved VT SR-PXD studies, i.e. a three-parameter space is mapped: composition, reactant ratio and temperature. Products obtained by mechanochemical synthesis are often mixtures of several compounds, which tend to hamper their identification using SR-PXD. ${ }^{[31]}$

The SR-PXD data analysis demonstrates that new unknown compounds can be structurally characterized also when they only exist as a minor fraction of the samples. The use of multiple powder patterns allows for solving structures of two or more new compounds present in the same sample by a method denoted "decomposition-aided indexing and structure solution". [40] The method depends on diffraction data measured at variable temperature, which allows grouping diffraction peaks according to their behaviour e.g. by peak intensity change or peak shift owing to decomposition, melting or a chemical reaction in the sample. Each group of reflections can be associated with a known compound or used for indexing and structure solution. High-temperature resolution allows selecting two patterns collected at relatively similar temperatures and differing only by the presence of an unknown compound. ${ }^{[41]}$

The Rietveld refinement profile of the pattern containing known compounds can be subtracted from the other pattern providing a difference plot, which can be used for indexing and structure solution of the unknown compound. The applicability of this approach was demonstrated for a ball-milled sample of $\mathrm{KBH}_{4}-\mathrm{CdCl}_{2}(1: 1)$. The data measured at approx. $75^{\circ} \mathrm{C}$, see Figure 2, contained diffracted intensities from both $\mathrm{KCd}\left(\mathrm{BH}_{4}\right)_{3}$ and $\mathrm{K}_{2} \mathrm{Cd}\left(\mathrm{BH}_{4}\right)_{4}$ whereas the data at approx. $85^{\circ} \mathrm{C}$ showed reflections only from $\mathrm{K}_{2} \mathrm{Cd}\left(\mathrm{BH}_{4}\right)_{4}$ besides the known compounds. Thus, the data measured at the higher temperature approx. $85^{\circ} \mathrm{C}$ were evaluated first and the structural model for $\mathrm{K}_{2} \mathrm{Cd}\left(\mathrm{BH}_{4}\right)_{4}$ was then used for evaluation of the data measured at approx. $75^{\circ} \mathrm{C}$.

In situ VT SR-PXD was measured for each of the twelve samples in the above-mentioned investigation and all observed diffracted intensities in the 875 collected PXD patterns are accounted for by eleven known compounds: $\mathrm{LiBH}_{4}, \mathrm{LiCl}$, $\mathrm{Li}_{2} \mathrm{CdCl}_{4}, \quad \mathrm{NaBH}_{4}, \mathrm{NaCl}, \mathrm{Na}_{2} \mathrm{CdCl}_{4}, \mathrm{Na}_{6} \mathrm{CdCl}_{8}, \mathrm{KBH}_{4}$, $\mathrm{KCdCl}_{3}, \mathrm{Cd}, \mathrm{CdCl}_{2}$, and four new cadmium borohydrides $\alpha$ $\mathrm{Cd}\left(\mathrm{BH}_{4}\right)_{2}, \beta-\mathrm{Cd}\left(\mathrm{BH}_{4}\right)_{2}, \mathrm{KCd}\left(\mathrm{BH}_{4}\right)_{3}, \mathrm{~K}_{2} \mathrm{Cd}\left(\mathrm{BH}_{4}\right)_{4} \cdot{ }^{[40]}$ Furthermore, sequential Rietveld refinement of the SR-PXD data provided a reliable estimate of the dynamic changes in the sample composition as a function of temperature, which is an efficient tool to analyse complex patterns of chemical reaction mechanisms. The reactions involve polymorphic transition, coupled reactions of borohydride decomposition, formation of ternary chlorides and their reaction with the excess reactants and with the decomposition products. Thus, this approach provides a unique platform for creating synergy between synthesis and characterization of novel materials. ${ }^{[40]}$

\section{2) Challenging Structural Evaluations}

Structural evaluation for new compounds containing both light and heavy elements can be challenging and the combined 

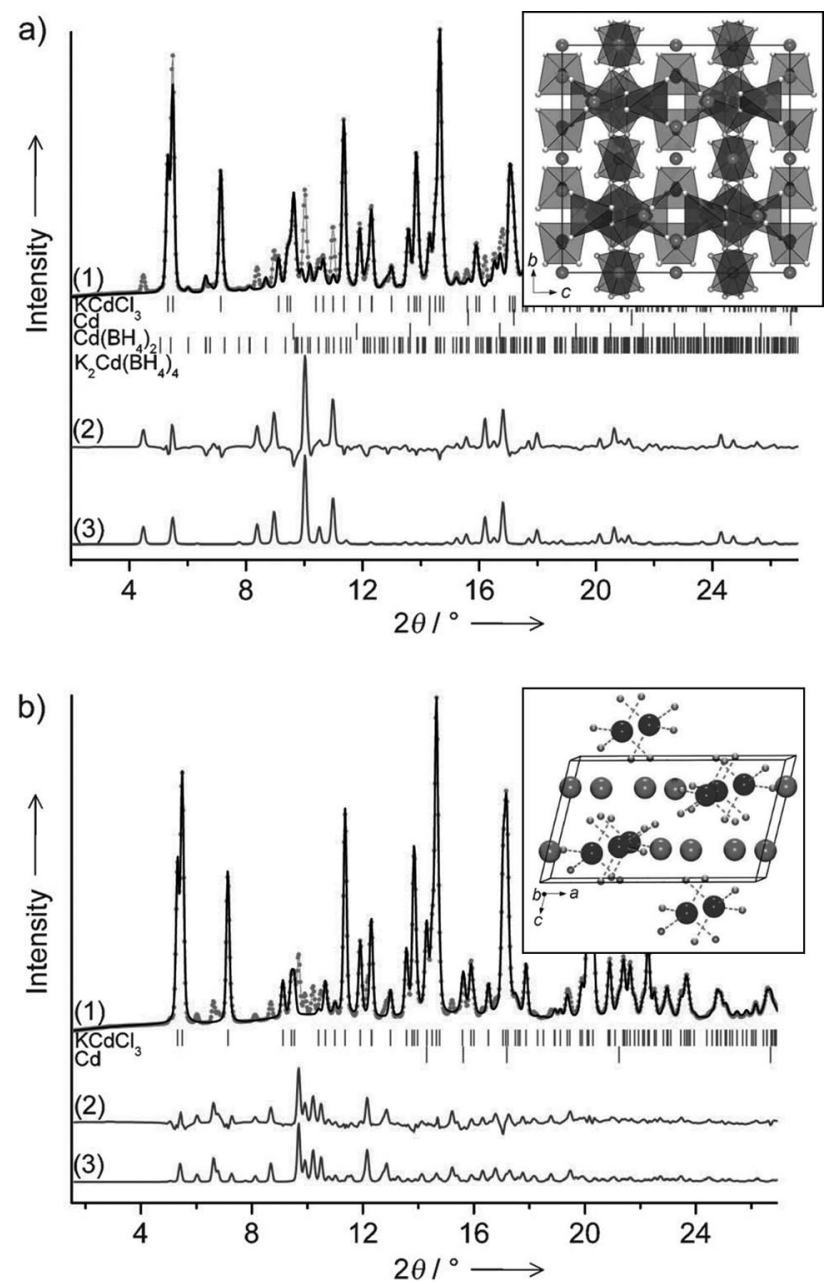

Figure 2. SR-PXD data measured for a ball milled sample of $\mathrm{KBH}_{4}-\mathrm{CdCl}_{2}(1: 1)$ at (a) approx. $75{ }^{\circ} \mathrm{C}$ and (b) approx. $85^{\circ} \mathrm{C}$, used for indexing and ab initio structure determination of $\mathrm{KCd}\left(\mathrm{BH}_{4}\right)_{3}$ and $\mathrm{K}_{2} \mathrm{Cd}\left(\mathrm{BH}_{4}\right)_{4}$, respectively (data collected at BM01A, ESRF, $\lambda=$ $0.700818 \AA$ ).${ }^{[40]}$ Curves show (1) observed data, $Y_{\text {obs }}$ (dots) and Rietveld refinement profile, $Y_{\text {calc }}$ (black curve) of structurally characterized compounds, i.e. novel compounds to be characterized are omitted from the model, (2) difference plot $Y_{\mathrm{obs}}-Y_{\text {calc }}$ and (3) calculated PXD pattern, $Y_{\text {calc }}$ using the structural model elucidated from the data, $\mathrm{KCd}\left(\mathrm{BH}_{4}\right)_{3}$ in (a) and $\mathrm{K}_{2} \mathrm{Cd}\left(\mathrm{BH}_{4}\right)_{4}$ in (b). Note the similarity between curves (2) and (3). The structures are shown as insets where polyhedra/ broken lines show $\mathrm{Cd}-\mathrm{B}$ connectivity.

use of several complementary techniques may be necessary, e.g. SR-PXD, powder neutron diffraction (PND) and/or density functional theory (DFT) in the search for a satisfactory structural model. ${ }^{[42]}$

Lithium cerium borohydride chloride, $\mathrm{LiCe}\left(\mathrm{BH}_{4}\right)_{3} \mathrm{Cl}$, was synthesized by mechanochemistry ${ }^{[39]}$ i.e. ball milling of samples of $\mathrm{CeCl}_{3}-\mathrm{LiBH}_{4}$ in various ratios. ${ }^{[25,43,44]}$ The $\mathrm{LiCe}\left(\mathrm{BH}_{4}\right)_{3} \mathrm{Cl}$ was eventually indexed and found to crystallize in a cubic structure, $a=11.7204(2) \AA$, with space-group $I \overline{4} 3 m$. Structural evaluation was performed on data obtained at approx. $160{ }^{\circ} \mathrm{C}$, as the new compound crystalized during heating. The position of electron-rich elements was readily localized by PXD but the positions of the lighter elements, $\mathrm{H}$ and $\mathrm{Li}$, revealed some ambiguity. The combined Rietveld refinement using SR-PXD and PND data revealed three possible structural models. However, DFT calculations of the models optimizing the energy of the structures arrived at a structural model for the $\mathrm{LiCe}\left(\mathrm{BH}_{4}\right)_{3} \mathrm{Cl}$ where $\mathrm{Li}$ ions occupy $2 / 3$ of the $12 d$ Wyckoff site corresponding to $8 \mathrm{Li}$ ions per unit cell. The structural model suggests that the compound might be a solid-state lithium ion conductor. ${ }^{[25]}$

The $\mathrm{Li}^{+}$conductivity was found to be $1.03 \times 10^{-4} \mathrm{~S} \mathrm{~cm}^{-1}$ at $T=20^{\circ} \mathrm{C}$, further supporting the structural model. Figure 3 illustrates the anions within the structure of $\mathrm{LiCe}\left(\mathrm{BH}_{4}\right)_{3} \mathrm{Cl}$, which is built from isolated tetranuclear clusters $\left[\mathrm{Ce}_{4} \mathrm{Cl}_{4}\left(\mathrm{BH}_{4}\right)_{12}\right]^{4-}$ (Figure 3) with distorted cubane-like cores of $\mathrm{Ce}_{4} \mathrm{Cl}_{4}$ and $\mathrm{Li}$ tetrahedrally coordinated to four $\left[\mathrm{BH}_{4}\right]^{-}$ groups. ${ }^{[25]}$ In conclusion, structural evaluation of $\mathrm{LiCe}\left(\mathrm{BH}_{4}\right)_{3} \mathrm{Cl}$ was only possible by the combined use of the three techniques SR-PXD, PND and DFT and likely not by any combination of two methods alone. The mixed-metal and anion-substituted rare earth metal borohydrides have been studied extensively. ${ }^{[25,43-47]}$ Among them, other fast $\mathrm{Li}^{+}$ion conductors isostructural to $\mathrm{LiCe}\left(\mathrm{BH}_{4}\right)_{3} \mathrm{Cl}$ have been discov-

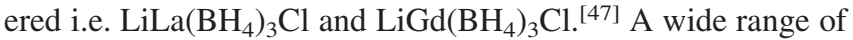
other bi- and trimetallic challenging and fascinating structures has also been characterized by SR-PXD. ${ }^{[48-52]}$

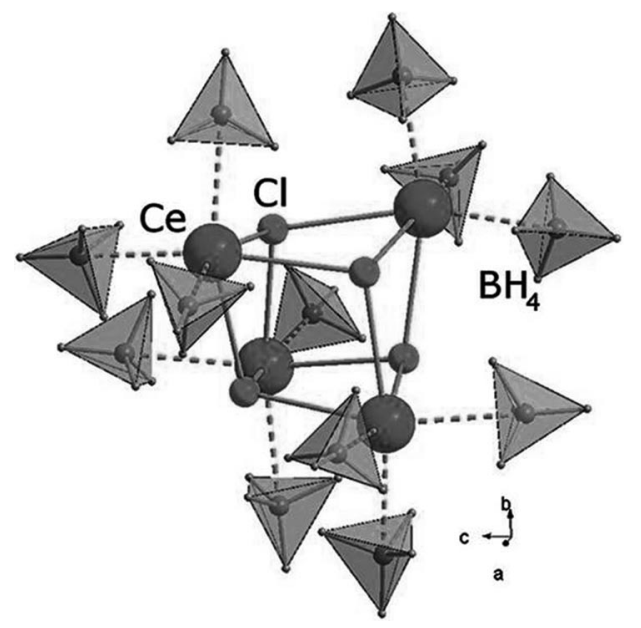

Figure 3. Isolated tetranuclear anionic cluster $\left[\mathrm{Ce}_{4} \mathrm{Cl}_{4}\left(\mathrm{BH}_{4}\right)_{12}\right]^{4-}$ with a distorted cubane $\mathrm{Ce}_{4} \mathrm{Cl}_{4}$ core discovered in the crystal structure of $\mathrm{LiCe}\left(\mathrm{BH}_{4}\right)_{3} \mathrm{Cl}^{[25]}$

\section{3) Hydrogen Release and Uptake from Reactive Hydride Composites}

Reactive hydride composites (RHC) may lead to a more energetically favourable decomposition pathway compared to the single compounds. ${ }^{[38,53,54]}$ The basic idea is that two or more hydrides react and form a new dehydrogenated state that improve thermodynamic and kinetic properties and facilitate hydrogen release and uptake. Independently, the research groups of J. J. Vajo, HRL, USA, Y. W. Cho, KIST, Korea and G. Barkhordarian, M. Dornheim, T. Klassen, R. Bormann, HZG (formerly GKSS), Germany, discovered several systems combining metal borohydrides and magnesium hydride, e.g. 
$\mathrm{LiBH}_{4}-\mathrm{MgH}_{2}, \mathrm{NaBH}_{4}-\mathrm{MgH}_{2}$ and $\mathrm{Ca}\left(\mathrm{BH}_{4}\right)_{2}-\mathrm{MgH}_{2} \cdot{ }^{[55-58]}$ Many interesting composites have been investigated during the past few years, e.g. $\mathrm{LiBH}_{4}-\mathrm{YH}_{3},{ }^{[59]} \mathrm{LiBH}_{4}-\mathrm{SrH}_{2},{ }^{[60]}$ and a promising and well-studied composite $\mathrm{LiBH}_{4}-\mathrm{MgH}_{2}(2: 1){ }^{[61-63]}$ The dehydrogenation mechanism of the latter is investigated with in situ SR-PXD (Figure 4), which reveals a two-step decomposition reaction, i.e. $\mathrm{MgH}_{2}$ decomposes to form $\mathrm{Mg}$ and gaseous $\mathrm{H}_{2}$, and finally $\mathrm{LiBH}_{4}$ and $\mathrm{Mg}$ react to form $\mathrm{LiH}$, $\mathrm{MgB}_{2}$ and $\mathrm{H}_{2}$ gas. ${ }^{[61]}$ Another benefit of RHC's is the possibility for rehydrogenation under less harsh conditions as compared to the pristine borohydride samples. Rehydrogenation of $\mathrm{LiBH}_{4}$ requires high pressure and temperature $\left(T=600{ }^{\circ} \mathrm{C}\right.$ and 155 bar $\left.\mathrm{H}_{2}\right),{ }^{[64]}$ whereas the desorbed $\mathrm{LiBH}_{4}-\mathrm{MgH}_{2}$, i.e. $\mathrm{LiH}-\mathrm{MgB}_{2}$ readily absorbs hydrogen already at $250-300{ }^{\circ} \mathrm{C}$ and 50 bar $\mathrm{H}_{2}$.

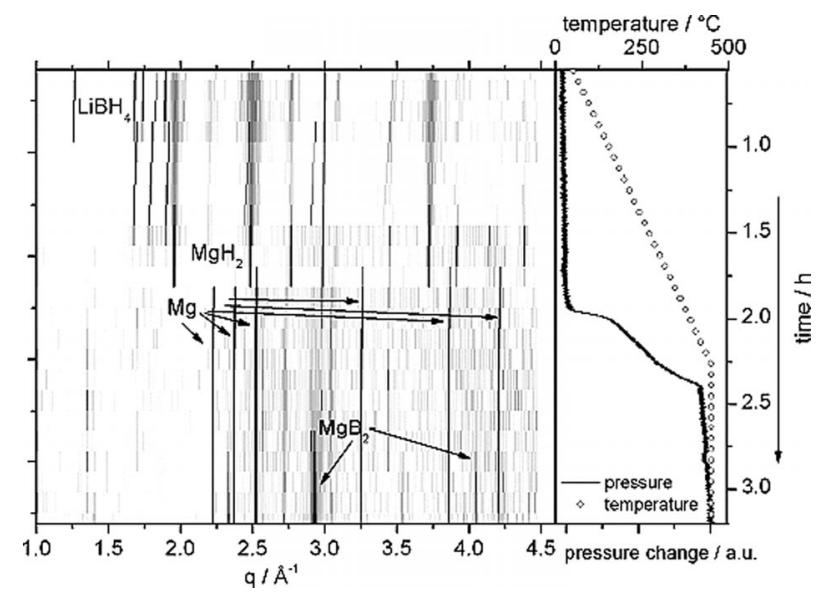

Figure 4. In situ SR-PXD data as a function of time and pressure for the dehydrogenation reaction of $\mathrm{LiBH}_{4}-\mathrm{MgH}_{2}$ measured at an initial pressure of $p\left(\mathrm{H}_{2}\right)=3$ bar in the temperature range $R T$ to $450{ }^{\circ} \mathrm{C}(\Delta T /$ $\Delta t=5{ }^{\circ} \mathrm{C} \mathrm{min}^{-1}, \lambda=0.5005 \AA$, data collected at SNBL, ESRF).${ }^{63]}$

Another system which enables hydrogen uptake at relatively benign conditions is the $\mathrm{LiBH}_{4}-\mathrm{MgH}_{2}-\mathrm{Al}$ system, which recently was investigated in the molar ratios $4: 1: 1$ and $4: 1: 5 .^{[65]}$ A detailed investigation of the reaction pathway was obtained by in situ SR-PXD measurements, which show interesting differences between the two samples. In $\mathrm{LiBH}_{4}-\mathrm{MgH}_{2}-\mathrm{Al}$ (4:1:1), a number of $\mathrm{Mg}-\mathrm{Al}$ intermediate compounds appear during hydrogen release, e.g. $\mathrm{Mg}_{17} \mathrm{Al}_{12}$ and $\mathrm{Mg}_{0.9} \mathrm{Al}_{0.1}$, whereas only $\mathrm{Mg}$ was observed as an intermediate in $\mathrm{LiBH}_{4}-\mathrm{MgH}_{2}-\mathrm{Al}$ (4:1:5). The combined use of both $\mathrm{MgH}_{2}$ and $\mathrm{Al}$ further lowers the temperature for hydrogen release as compared to the RHC's with either $\mathrm{MgH}_{2}$ or Al. ${ }^{[61,62,66,67]}$ The most significant decrease in hydrogen release temperature is observed in $\mathrm{LiBH}_{4}-\mathrm{MgH}_{2}-\mathrm{Al}$ (4:1:5), likely owing to absence of $\mathrm{Mg}-\mathrm{Al}$ intermediates.

The hydrogen absorption at $p\left(\mathrm{H}_{2}\right)=100$ bar of $\mathrm{LiBH}_{4}-\mathrm{MgH}_{2}-\mathrm{Al}$ (4:1:5) is presented in Figure 5. During heating, at approximately $T \approx 350{ }^{\circ} \mathrm{C}$, the diffracted intensity from $\mathrm{LiAl}$ and $\mathrm{Mg}_{x} \mathrm{Al}_{1-x} \mathrm{~B}_{2}$ disappears, and diffracted intensity from $\mathrm{Al}$ is observed, corresponding to the chemical reaction in Equation 1:

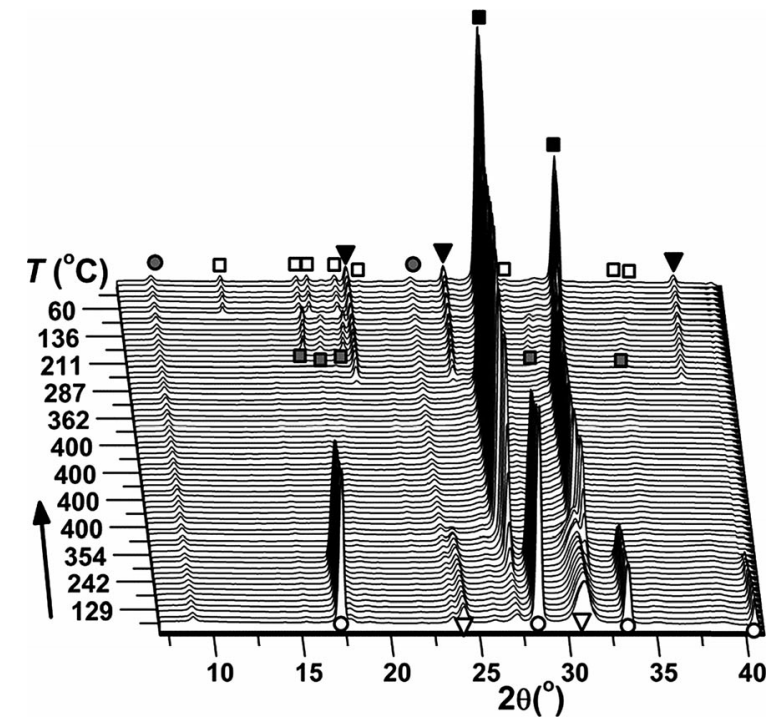

Figure 5. In situ SR-PXD data of hydrogen absorption for a dehydrogenated sample of $\mathrm{LiBH}_{4}-\mathrm{MgH}_{2}-\mathrm{Al}(4: 1: 5)$ measured at $p\left(\mathrm{H}_{2}\right)$ $=100 \mathrm{bar}$ in the temperature range from $R T$ to $400{ }^{\circ} \mathrm{C}\left(\Delta T / \Delta t=15^{\circ} \mathrm{C}\right.$ $\min ^{-1}, \lambda=1.1021 \AA$, data collected at beamline I711 at MAX-Lab). The sample was kept at a constant temperature of $400{ }^{\circ} \mathrm{C}$ for $60 \mathrm{~min}$ before cooling to room temp. $\left(\Delta T / \Delta t=-10{ }^{\circ} \mathrm{C} \mathrm{min}-1\right.$ ). Symbols: (white squares) $o-\mathrm{LiBH}_{4}$, (gray squares) $h-\mathrm{LiBH}_{4}$, (black squares) $\mathrm{Al}$, (black triangles) $\mathrm{MgH}_{2}$, (white triangles) $\mathrm{Mg}_{x} \mathrm{Al}_{1-x} \mathrm{~B}_{2}$, (white circles) LiAl and (gray circles) Unknown. ${ }^{[65]}$

$2 \mathrm{LiAl}(s)+\operatorname{Mg}_{x} \mathrm{Al}_{1-x} \mathrm{~B}_{2}(s)+(4+x) \mathrm{H}_{2}(g) \rightarrow 2 \mathrm{LiBH}_{4}(l)+x \mathrm{MgH}_{2}(l)+$ $(3-x) \operatorname{Al}(s)$

During cooling $\mathrm{MgH}_{2}$ and $h-\mathrm{LiBH}_{4}$ crystallize from the melt at approx. 285 and approx. $270{ }^{\circ} \mathrm{C}$, respectively. The phase transformation from $h$ - to $o-\mathrm{LiBH}_{4}$ is observed at $T \approx 100{ }^{\circ} \mathrm{C}$. The system is reversible at the applied physical conditions and comparison of Rietveld refinements of the data collected before desorption and after absorption shows that approximately $55 \% \mathrm{LiBH}_{4}$ and $98 \% \mathrm{MgH}_{2}$ are reformed after approx. $1 \mathrm{~h}$ of hydrogenation.

\section{4) A New Solid Solution Discovered in the $\mathrm{LiAlH}_{4}-\mathrm{LiNH}_{2}$ Composite.}

The decomposition pathway for the composite $\mathrm{LiAlH}_{4}-\mathrm{LiNH}_{2}$ in different reactant ratios was systematically studied using in situ SR-PXD. ${ }^{[68]}$ This study revealed that $\mathrm{LiAlH}_{4}$ decomposes in two steps according to Equations 2 and 3 as for $\mathrm{LiAlH}_{4}$ :

$\mathrm{LiAlH}_{4}(\mathrm{~s}) \rightarrow 1 / 3 \mathrm{Li}_{3} \mathrm{AlH}_{6}(\mathrm{~s})+2 / 3 \mathrm{Al}(\mathrm{s})+\mathrm{H}_{2}(\mathrm{~g})$

$\mathrm{Li}_{3} \mathrm{AlH}_{6}(\mathrm{~s}) \rightarrow 3 \mathrm{LiH}(\mathrm{s})+\mathrm{Al}(\mathrm{s})+3 / 2 \mathrm{H}_{2}(\mathrm{~g})$

The produced $\mathrm{LiH}$ then reacts with $\mathrm{LiNH}_{2}$ to form $\mathrm{Li}_{2} \mathrm{NH}$ and $\mathrm{H}_{2}$ according to Equation 4 .

$\mathrm{LiH}(\mathrm{s})+\mathrm{LiNH}_{2}(\mathrm{~s}) \rightarrow \mathrm{Li}_{2} \mathrm{NH}(\mathrm{s})+\mathrm{H}_{2}(\mathrm{~g})$

Additionally, the reflections of $\mathrm{Li}_{2} \mathrm{NH}$ and $\mathrm{Al}$ decrease in intensity in the temperature range 380 to $480{ }^{\circ} \mathrm{C}$ along with the increase in intensity of a new set of diffraction peaks assigned 
to the formation of a new solid solution, $\mathrm{Li}_{4-x} \mathrm{Al}_{x}(\mathrm{NH})_{2-2 x} \mathrm{~N}_{2 x}$, according to Equation 5

$2 \mathrm{Li}_{2} \mathrm{NH}(\mathrm{s})+x \mathrm{Al}(\mathrm{s}) \rightarrow \mathrm{Li}_{4-x} \mathrm{Al}_{x}(\mathrm{NH})_{2-2 x} \mathrm{~N}_{2 x}(\mathrm{~s})$

$+x \mathrm{LiH}(\mathrm{s})+x / 2 \mathrm{H}_{2}(\mathrm{~g})$

The solid solution $\mathrm{Li}_{4-x} \mathrm{Al}_{x}(\mathrm{NH})_{2-2 x} \mathrm{~N}_{2 x}$ was initially characterized by Rietveld refinement of SR-PXD data and found to crystallize in a cubic unit cell, $a=4.9854(7) \AA$ with space group $F m 3<\ddot{\mathrm{U}}->m$. The structure is isostructural to $\mathrm{Li}_{2} \mathrm{NH}$ with both cation and anion disorder, which is rarely observed. The structure is built from regular $\left[\mathrm{Li} / \mathrm{AlN}_{4}\right]$ tetrahedra sharing all six edges with neighbouring tetrahedra and all four corners with four $\left[\mathrm{Li} / \mathrm{AlN}_{4}\right]$ tetrahedra (see Figure 6). ${ }^{[68]}$

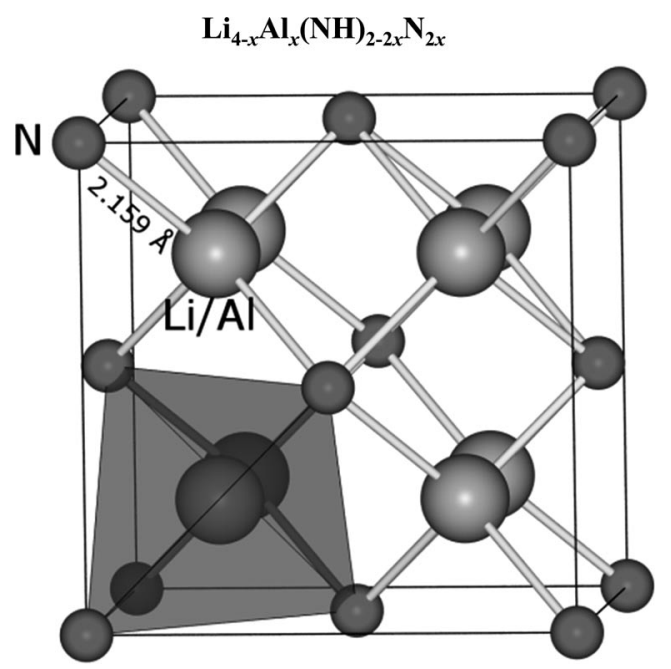

Figure 6. The crystal structure of $\mathrm{Li}_{4-x} \mathrm{Al}_{x}(\mathrm{NH})_{2-2 x} \mathrm{~N}_{2 x}$, which is isostructural to $\mathrm{Li}_{2} \mathrm{NH}$. [Li/AlN $\left.{ }_{4}\right]$ tetrahedra are shown as light gray polyhedra. ${ }^{[68]}$

Moreover, the bond lengths Li/Al-N (2.159 $\AA$ ) are similar to the $\mathrm{Li}-\mathrm{N}$ distances in $\mathrm{Li}_{3} \mathrm{AlN}_{2}(2.152-2.163 \AA$ ) but slightly shorter than the $\mathrm{Li}-\mathrm{N}$ distance in $\mathrm{Li}_{2} \mathrm{NH}(2.185 \AA$ ).

The two complementary techniques, ${ }^{27} \mathrm{Al}$ MAS NMR and Rietveld refinement of SR-PXD data, both revealed a maximum value for $x$ of approx. 0.10 , i.e., $\mathrm{Li}_{3.90} \mathrm{Al}_{0.10}(\mathrm{NH})_{1.80} \mathrm{~N}_{0.20}$. Higher aluminium contents result in cation ordering and crystallization of $\mathrm{Li}_{3} \mathrm{AlN}_{2}$. Furthermore, the composition of the solid solution, $x$, varies with temperature as seen by a continuous change in $2 \theta$ position for the Bragg peaks (see inset in Figure 7). At higher temperatures, the diffracted intensity of the solid solution decreases while those from $\mathrm{Li}_{3} \mathrm{AlN}_{2}$ and $\mathrm{LiH}$ increase in intensity. Thus, the PXD data allow direct observation of a new intermediate solid solution, determination of the structure, composition and stability as a function of temperature. ${ }^{[68]}$

\section{5) Anion Substitution in Solids}

Anion substitution has been suggested as an alternative way to alter thermodynamics of hydrogen storage properties of metal borohydrides. ${ }^{[13,38,69,70]}$ Thus, the dissolution of solid sodium chloride and sodium borohydride into each other resulting in formation of solid solutions of composition

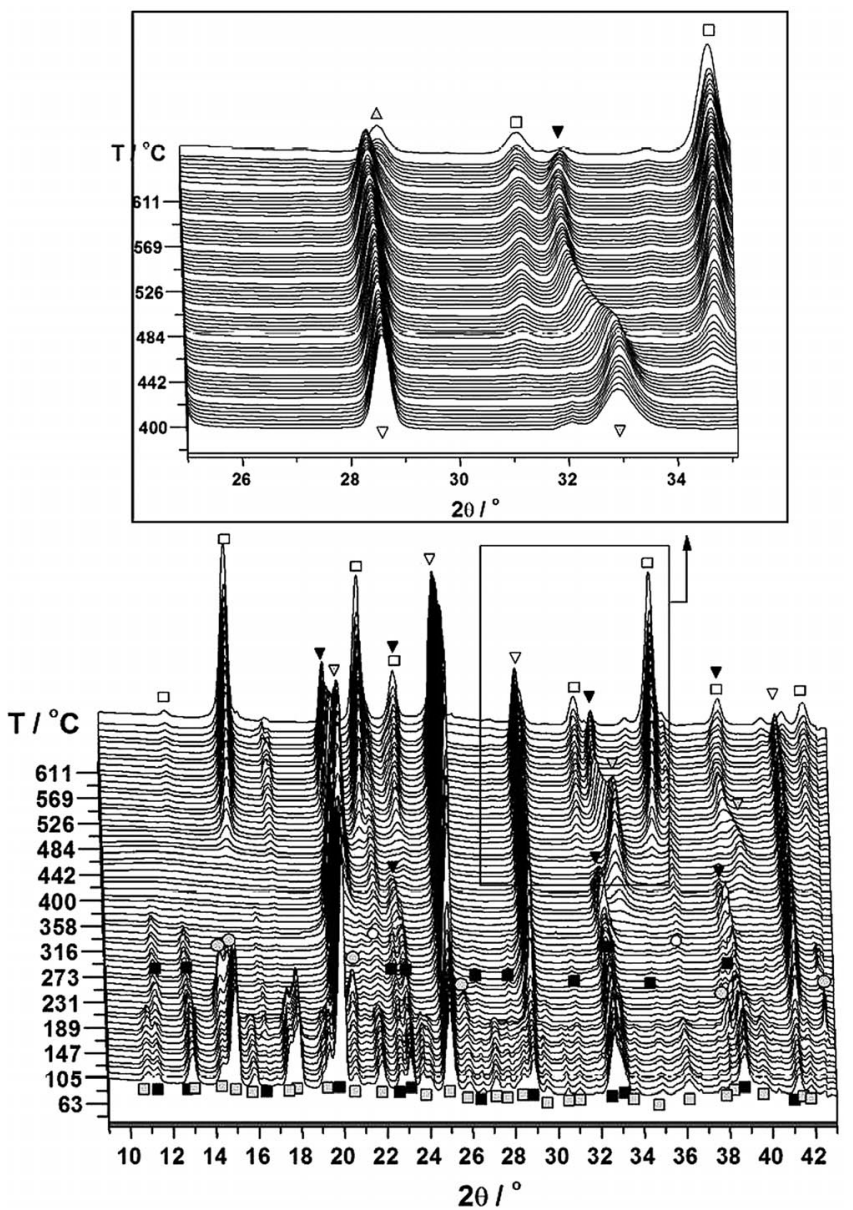

Figure 7. In situ SR-PXD diffractograms for $\mathrm{LiAlH}_{4}-\mathrm{LiNH}_{2}$ (1:2) heated from $R T$ to $635^{\circ} \mathrm{C}\left(5^{\circ} \mathrm{C} \mathrm{min}^{-1}\right.$, dynamic vacuum, $\lambda=$ $1.00989 \AA$, collected at beamline I711 at MAX-Lab). Symbols: (black squares) $\mathrm{LiNH}_{2}$; (gray squares) $\mathrm{LiAlH}_{4}$; (gray circles) $\mathrm{Li}_{3} \mathrm{AlH}_{6}$; (white circles) $\mathrm{Li}_{2} \mathrm{O}$; (black triangles) $\mathrm{Li}_{2} \mathrm{NH}$; (gray triangles) $\mathrm{Li}_{4-x} \mathrm{Al}_{x}(\mathrm{NH})_{2-2 x} \mathrm{~N}_{2 x}$; (white triangles) $\mathrm{Al}$; (white squares) $\mathrm{Li}_{3} \mathrm{AlN}_{2}{ }^{[68]}$

$\mathrm{Na}\left(\mathrm{BH}_{4}\right)_{1-x} \mathrm{Cl}_{x}$ was studied. ${ }^{[71,72]}$ The dissolution reaction was facilitated by two methods: mechanochemistry (ball milling) or combination of ball milling and subsequent annealing at elevated temperature i.e. heating of $\mathrm{NaBH}_{4}-\mathrm{NaCl}$ at $300{ }^{\circ} \mathrm{C}$ for $3 \mathrm{~d}^{\left[{ }^{[71]}\right.}$ The powder diffraction patterns of $\mathrm{NaBH}_{4}-\mathrm{NaCl}$ (0.5:0.5) before and after annealing are very different due to formation of solid solutions, see Figure 8. Additionally, the unit cell contraction owing to substitution of the larger $\mathrm{BH}_{4}^{-}$ anion $\left(r=2.05 \AA\right.$ ) with the smaller $\mathrm{Cl}^{-}$anion $(r=1.81 \AA)$, follows Vegard's law. ${ }^{[71,72]}$

Rietveld refinement of in situ SR-PXD data was utilized in determining the degree of dissolution (Figure 9). Ball milling resulted in dissolution of 10 mol- $\% \mathrm{NaCl}$ into $\mathrm{NaBH}_{4}$, forming $\mathrm{Na}\left(\mathrm{BH}_{4}\right)_{0.9} \mathrm{Cl}_{0.1}$. A higher degree of dissolution of $\mathrm{NaCl}$ in $\mathrm{NaBH}_{4}$ was obtained by annealing at $T>240{ }^{\circ} \mathrm{C}$ providing $\mathrm{Na}\left(\mathrm{BH}_{4}\right)_{0.43} \mathrm{Cl}_{0.57}$. In addition, annealing resulted in dissolution of $10-20$ mol-\% $\mathrm{NaBH}_{4}$ into $\mathrm{NaCl}$. The rate of dissolution of $\mathrm{NaCl}$ in $\mathrm{NaBH}_{4}$ was also extracted from the SR-PXD data and found to be linear with a rate of $0.105(3) \mathrm{mol}-\% \mathrm{Cl}^{-}$ $\min ^{-1}$ at $300{ }^{\circ} \mathrm{C}^{\left[{ }^{[71]}\right.}$ 

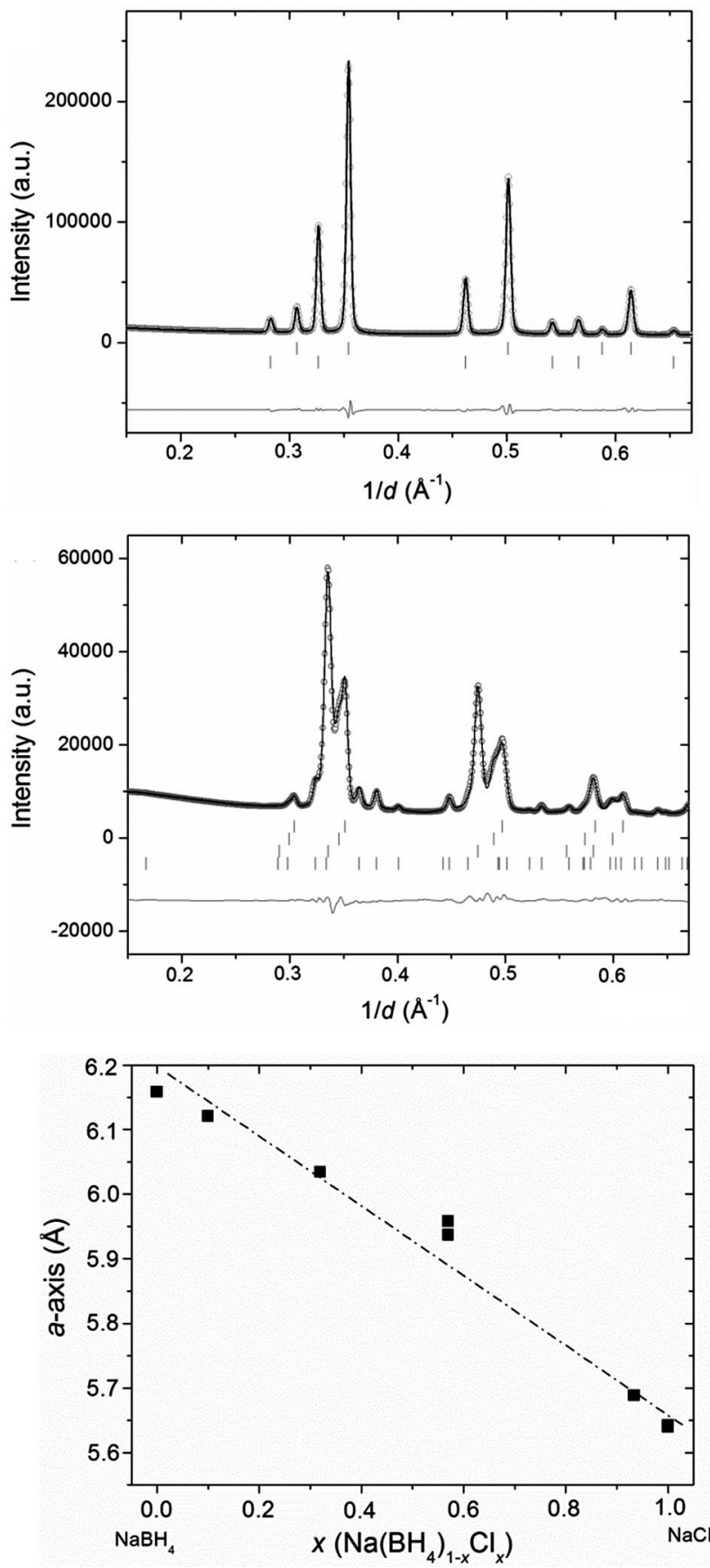

Figure 8. Rietveld refinement of SR-PXD data of top: ball-milled $\mathrm{NaBH}_{4}-\mathrm{NaCl}(0.5: 0.5)$ and middle: $\mathrm{NaBH}_{4}-\mathrm{NaCl}(0.5: 0.5$, annealed). Bottom: The unit cell parameter, $a$, varies with composition in regard to Vegard's law. ${ }^{[71]}$

\section{6) Heat of Adsorption Extracted from PXD Data}

$\mathrm{Mg}\left(\mathrm{BH}_{4}\right)_{2}$ is a well-studied material, ${ }^{[73-77]}$ however, several new polymorphs have been discovered recently, i.e. $\beta^{\prime}-, \varepsilon^{-}, \gamma-$ and $\delta-\mathrm{Mg}\left(\mathrm{BH}_{4}\right)_{2} \cdot{ }^{[10,78-84]}$ The polymorph $\gamma-\mathrm{Mg}\left(\mathrm{BH}_{4}\right)_{2}$ is the first reported nanoporous metal borohydride with a large permanent porosity (approx. $33 \%$ void space) and pore size of $8.8 \AA$. The structure is cubic, $a=15.7575(16) \AA$ (space group $I d 3<\ddot{\mathrm{U}}->a$ ), and was solved using SR-PXD data. The SRPXD data also confirm that this compound adsorbs smaller

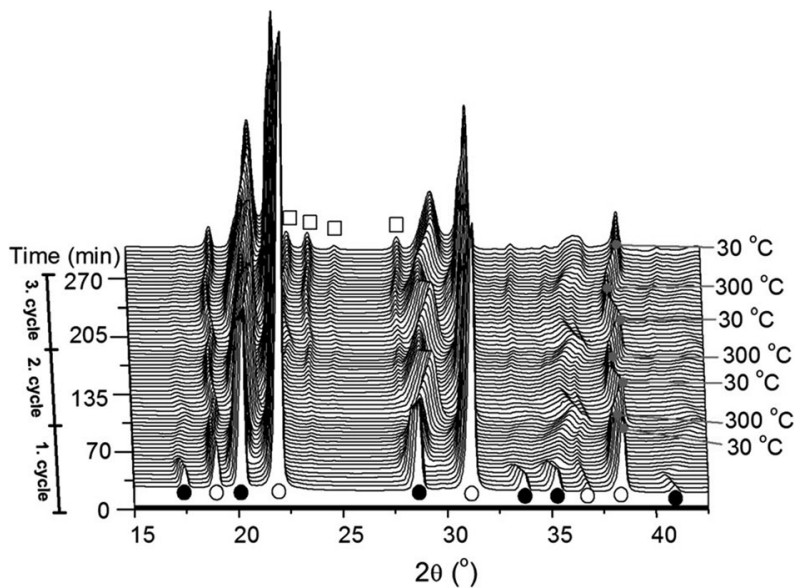

Figure 9. In situ SR-PXD data of ball milled $\mathrm{NaBH}_{4}-\mathrm{NaCl}(0.5: 0.5)$, heated from $R T$ to $300^{\circ} \mathrm{C}\left(\Delta T / \Delta t=10^{\circ} \mathrm{C} / \mathrm{min}, \lambda=1.072(2) \AA\right.$, collected at beamline $\mathrm{I} 711$ at MAX-Lab), kept at $300{ }^{\circ} \mathrm{C}$ for $30 \mathrm{~min}$, cooled from $300{ }^{\circ} \mathrm{C}$ to room temp. and cycled 3 times. Symbols: (white circles) $\mathrm{NaCl}$, (black circles) $\mathrm{NaBH}_{4}$ and (white squares) $\mathrm{NaBO}_{2}$. ${ }^{[71]}$

molecules reversibly, such as $\mathrm{H}_{2}, \mathrm{~N}_{2}$ and $\mathrm{CH}_{2} \mathrm{Cl}_{2}$ and the exact position of the adsorbed gas molecules can be located. The molecules interact with the $\mathrm{BH}_{4}{ }^{-}$units in the structure, thus revealing new physisorption interactions. ${ }^{[10]}$

Gas adsorption was successfully investigated by in situ SRPXD heating a closed, isobar sample container. The isosteric heats of adsorption of nitrogen and hydrogen in $\gamma-\mathrm{Mg}\left(\mathrm{BH}_{4}\right)_{2}$ were determined from in situ SR-PXD data to be $Q_{\mathrm{st}}\left(\mathrm{N}_{2}\right) \approx$ $15 \mathrm{~kJ} \mathrm{~mol}^{-1}$ and $Q_{\mathrm{st}}\left(\mathrm{H}_{2}\right) \approx 6 \mathrm{~kJ} \mathrm{~mol}^{-1}$ (average values) and $Q_{\mathrm{st}}$ $>7 \mathrm{~kJ} \mathrm{~mol}^{-1}$ at a loading of $15 \mathrm{mg} \mathrm{H}_{2} \mathrm{~g}^{-1}{ }^{[10]}$ The latter value is among the highest values measured for MOFs and other porous solids. ${ }^{[85,86]}$ Thus, in situ SR-PXD is superior to other experimental approaches by providing direct measurement of the quantitative amount of gas adsorbed in the interior of nanoporous materials along with the exact host-guest interactions, i.e. position of adsorbed gas molecules. ${ }^{[10]}$. Additionally, information of thermodynamic and kinetic data of gas release and uptake can be extracted. A drawback is that only the crystalline fraction of the sample is probed and amorphous material may not be characterised.

\section{7) Niobium Oxide as an Additive for Magnesium Hydride}

Magnesium hydride is suggested as a potential hydrogen storage material but the kinetics for hydrogen release and uptake needs to be improved, e.g. by utilisation of additives. ${ }^{[53,87,88]}$ The surface oxide layer $(\mathrm{MgO})$, which covers magnesium metal is considered almost impermeable to hydrogen and decreases the kinetics of (de)hydrogenation significantly. ${ }^{[89]}$ However, niobium pentaoxide, $\mathrm{Nb}_{2} \mathrm{O}_{5}$, has proven to be one of the most effective additives mediating fast release and uptake ${ }^{[53,87,88,90,91]}$ and investigations of the system $\mathrm{MgH}_{2}-\mathrm{Nb}_{2} \mathrm{O}_{5}$ using SR-PXD have provided a possible explanation for this effect. ${ }^{[2-95]}$

Three samples of $\mathrm{MgH}_{2}-\mathrm{Nb}_{2} \mathrm{O}_{5}$ (8 mol-\%) ball-milled to different extents were investigated in real time during up to eight continuous full hydrogen release and uptake cycles. Rela- 


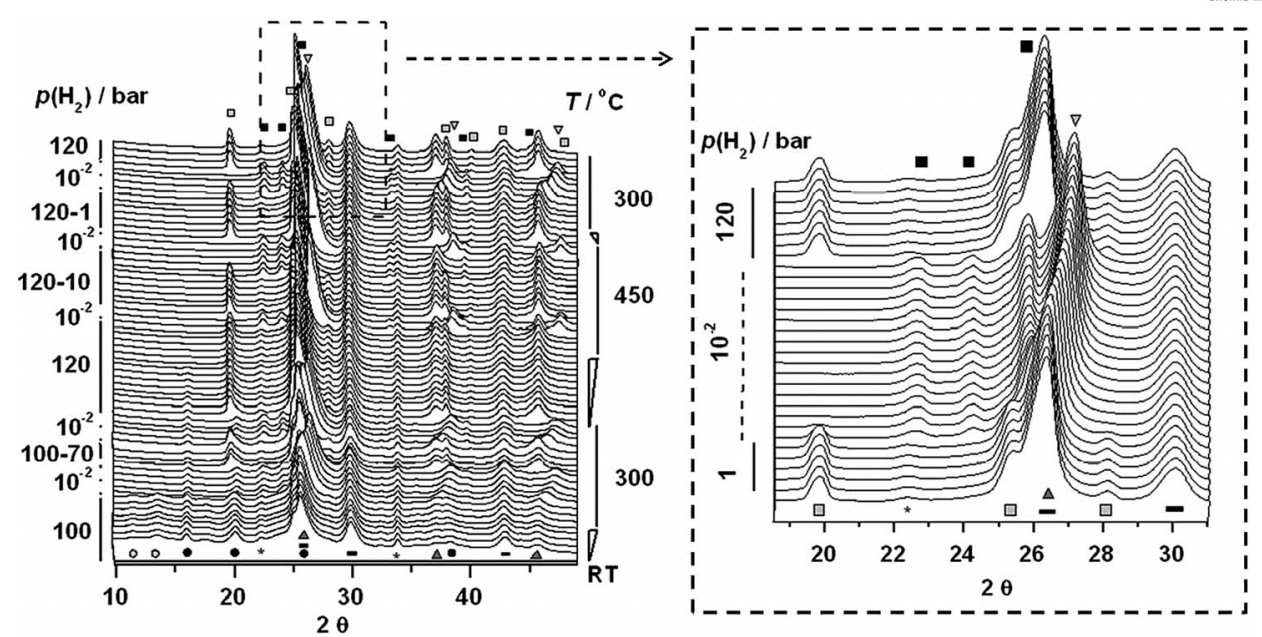

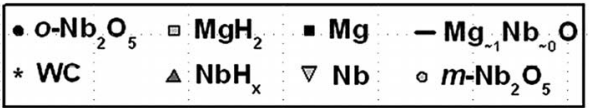

Figure 10. In situ SR-PXD data of $\mathrm{MgH}_{2}-\mathrm{Nb}_{2} \mathrm{O}_{5}(8 \mathrm{~mol} \%)$ showing the hydrogen release and uptake when heated stepwise from $R T$ to 300 and $450{ }^{\circ} \mathrm{C}$ (left). Hydrogen pressure was varied between $p\left(\mathrm{H}_{2}\right)=10^{-2}$ and 120 bar. Hydrogen release and uptake in cycle $5, T=300{ }^{\circ} \mathrm{C}$, after heating to $450{ }^{\circ} \mathrm{C}$ (right). Time propagates from bottom to top $\left(\lambda=1.0980 \AA\right.$, beamline I711 at MAX-Lab). ${ }^{[12]}$

tively large amounts of additive were used in order to allow a clearer detection of the chemical reactions in the system $\mathrm{Mg}$ $\mathrm{MgH}_{2}-\mathrm{Nb}_{2} \mathrm{O}_{5}$. An in situ SR-PXD pattern is provided in Figure $10 .{ }^{[12]}$

Rietveld refinement analysis suggested that a reaction between $\mathrm{MgH}_{2}$ and $\mathrm{Nb}_{2} \mathrm{O}_{5}$ occurs during sample preparation i.e. ball milling, which produces the ternary oxide $\mathrm{Mg}_{x} \mathrm{Nb}_{1-x} \mathrm{O}$. At elevated temperatures a reaction between $\mathrm{Mg}$ and $\mathrm{Nb}_{2} \mathrm{O}_{5}$ occurs forming a ternary oxide, with composition $\mathrm{Mg}_{0.60} \mathrm{Nb}_{0.40} \mathrm{O}$ obtained when assuming an oxidation state +2 for $\mathrm{Nb}$ (see Equation (6)). This may indicate an upper limit for the niobium content in the solid solution of 40 mol-\%. ${ }^{[12]}$

$3 \mathrm{Mg}(\mathrm{s})+\mathrm{Nb}_{2} \mathrm{O}_{5}(\mathrm{~s}) \rightarrow 5 \mathrm{Mg}_{0.60} \mathrm{Nb}_{0.40} \mathrm{O}(\mathrm{s})$

More extreme mechanochemical conditions or cycling of the $\mathrm{MgH}_{2}-\mathrm{Nb}_{2} \mathrm{O}_{5}$ composite with hydrogen release and uptake at $T>300{ }^{\circ} \mathrm{C}$ lead to formation of niobium or niobium hydride, i.e. niobium is extracted from the ternary solid solution by reduction of $\mathrm{Nb}^{\mathrm{II}}$ as illustrated in reaction Equation 7. Finally $\mathrm{MgO}$ (or $\mathrm{Mg}_{\approx 1} \mathrm{Nb}_{\approx 0} \mathrm{O}$ ) and $\mathrm{Nb}$ will form.

$5 \mathrm{Mg}_{0.60} \mathrm{Nb}_{0.40} \mathrm{O}(\mathrm{s})+2 \mathrm{Mg}(\mathrm{s}) \rightarrow 5 \mathrm{MgO}(\mathrm{s})+2 \mathrm{Nb}(\mathrm{s})$

Formation and stabilization of the ternary oxide appear to be important for the prolific kinetic effect of $\mathrm{Nb}_{2} \mathrm{O}_{5}$ as additive in $\mathrm{MgH}_{2} \cdot{ }^{[96]}$ Furthermore, diffusion of hydrogen through bulk niobium inclusions in $\mathrm{MgO}$ may be faster as compared to diffusion in bulk $\mathrm{MgO}$ (see Figure 10). ${ }^{[12]}$

Rietveld refinements and the stoichiometry are plotted as a function of hydrogen release and uptake cycle number in Figure 11 and the initial $\mathrm{Mg}$ content in the ternary solid solution is $\mathrm{Mg}_{0.2} \mathrm{Nb}_{0.8} \mathrm{O}$. The relative $\mathrm{Mg}$ content in the ternary solid solution increases when the sample is heated and cycled with hydrogen, especially during the first four cycles, and apparently reaches a maximum. The composition after eight hydrogen release and uptake cycles is $\mathrm{Mg}_{0.58} \mathrm{Nb}_{0.42} \mathrm{O}$ in accord with Equation 6.

The unit cell volume is plotted as a function of the composition of the solid solution $\mathrm{Mg}_{x} \mathrm{Nb}_{1-x} \mathrm{O}$, in Figure 11 revealing a positive deviation from Vegard's law. ${ }^{[97]}$ Furthermore, the enlargement in Figure 11 reveals a linear correlation between the unit cell volume and the composition of $\mathrm{Mg}_{x} \mathrm{Nb}_{1-x} \mathrm{O}$ in the range approx. $0.2<x<$ approx. 0.6. ${ }^{[12]}$

The significant volume expansion observed for $\mathrm{Mg}_{x} \mathrm{Nb}_{1-x} \mathrm{O}$ as compared to the two binary oxides, $\mathrm{MgO}$ and $\mathrm{NbO}$, may contribute to the prolific properties of $\mathrm{Nb}_{2} \mathrm{O}_{5}$ used as additive in $\mathrm{MgH}_{2}$ for the release and uptake of hydrogen. The evolution of $\mathrm{Mg}_{x} \mathrm{Nb}_{1-x} \mathrm{O}$ is expected to form cracks in the otherwise dense surface layer of magnesium oxide. The increased number of diffusion pathways through the $\mathrm{MgO}$ layer may significantly enhance the kinetics for hydrogen release and uptake in $\mathrm{Mg} / \mathrm{MgH}_{2} \cdot{ }^{[96]}$

\section{8) Kinetic Analysis of Hydrogen Release.}

In situ SR-PXD is also a well-documented method for extracting kinetic data, e.g. when measured under isothermal conditions. Integration of the diffracted intensity from one or several strong, well-resolved reflections from each compound in each powder pattern is the raw data that initially needs to be extracted. Phase fractions, $\alpha_{\mathrm{i}}(t)$, describing the degree of formation or decomposition of compound $i$ can then be calculated and normalized using Equation (8):

$\alpha_{\mathrm{i}}(t)=\Sigma I_{\mathrm{i}}(t) / I_{\mathrm{i}, \max }$

where $I_{\mathrm{i}}(t)$ is the integrated diffracted intensity for compound $i$ at time $t$ and $I_{\max }$ is the maximum observed intensity. A variety of different models can be used to analyse the kinetic data 

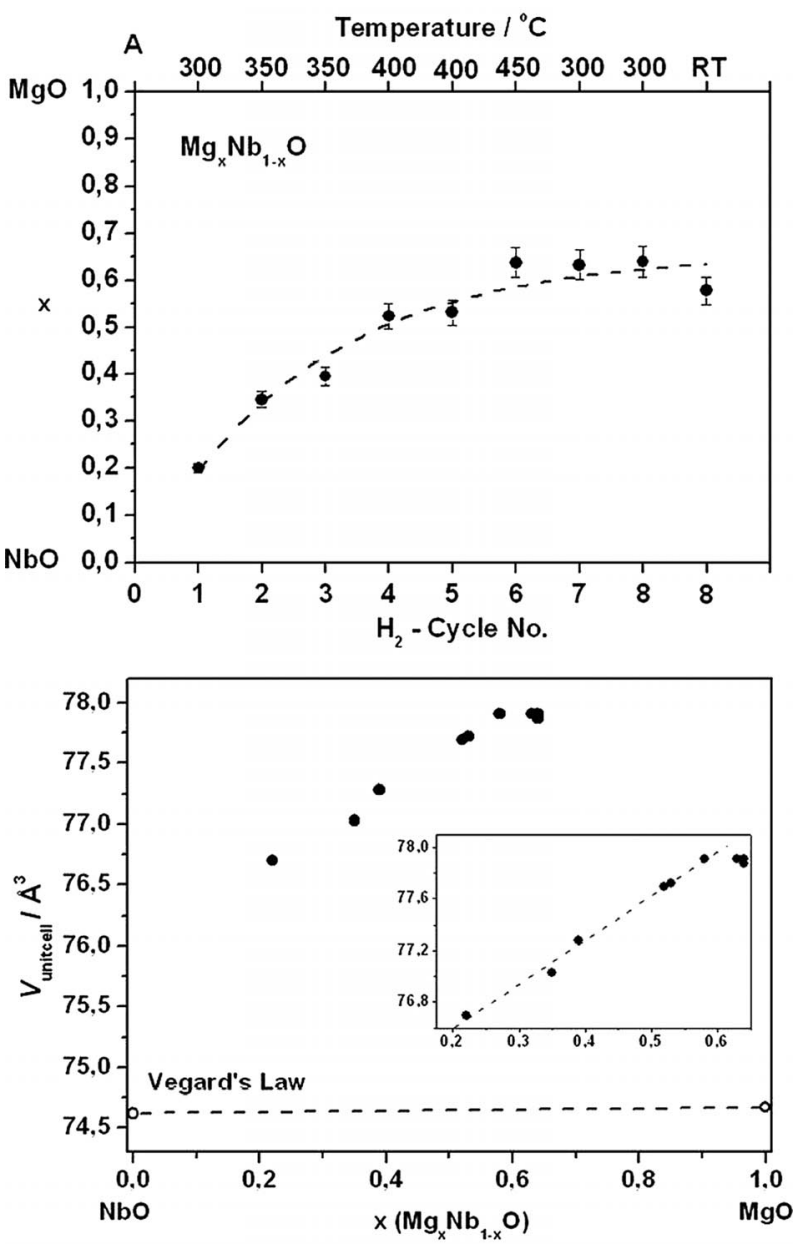

Figure 11. The composition of the solid solution $\mathrm{Mg}_{x} \mathrm{Nb}_{1-x} \mathrm{O}$ obtained by Rietveld refinements (black circles) of selected SR-PXD diagrams (the dashed line is a guide to the eye) (top). The unit cell volume as a function of the composition, $x$, for the ternary solid solution $\mathrm{Mg}_{x} \mathrm{Nb}_{1-x} \mathrm{O}$ (bottom). The dashed line (between literature values of $V(\mathrm{MgO})$ and $V(\mathrm{NbO})$ open circles) indicates Vegard's law. The enlargement shows a linear correlation between the observed unit cell volume and the composition of the ternary phase. ${ }^{[12]}$

and the Johnson-Mehl-Avrami (JMA) type nucleation and growth rate equation is among the most frequently used: ${ }^{[62]}$

$\alpha(t)=\exp \left(-(k t)^{n}\right)$

The rate constants, $k$, and the Avrami exponent, $n$ contain information about nucleation and growth rates. The value of $k$ is usually determined from the middle part of the crystallization curve, e.g. $0.3<\alpha(t)<0.7$, and is less sensitive to the specific choice of kinetic model. ${ }^{[98-100]}$ The time for $50 \%$ conversion of compound $i$ in the reaction mixture, $\alpha_{\mathrm{i}}(t)=0.5$, is sometimes denoted $t_{\mathrm{z}}$ and consists of two contributions. The delay time where no diffraction is observed can be assigned to a nucleation time, $t_{0}$, and the time from the first observation of weak diffraction of compound $i$ to $\alpha_{\mathrm{i}}(t)=0.5$ can be denoted $t_{1 / 2}$.

$t_{\mathrm{z}}=t_{0}+t_{1 / 2}$

In most cases, the rate constant, $k$, does not refer to a specific mechanism or actual concentrations of reactants, but can be used to estimate an apparent activation energy, $E_{\mathrm{A}}$. The apparent activation energy is readily extracted using the conventional Arrhenius expression, i.e. by plotting $\ln k$ vs. $1 / T$, (see Figure 12):
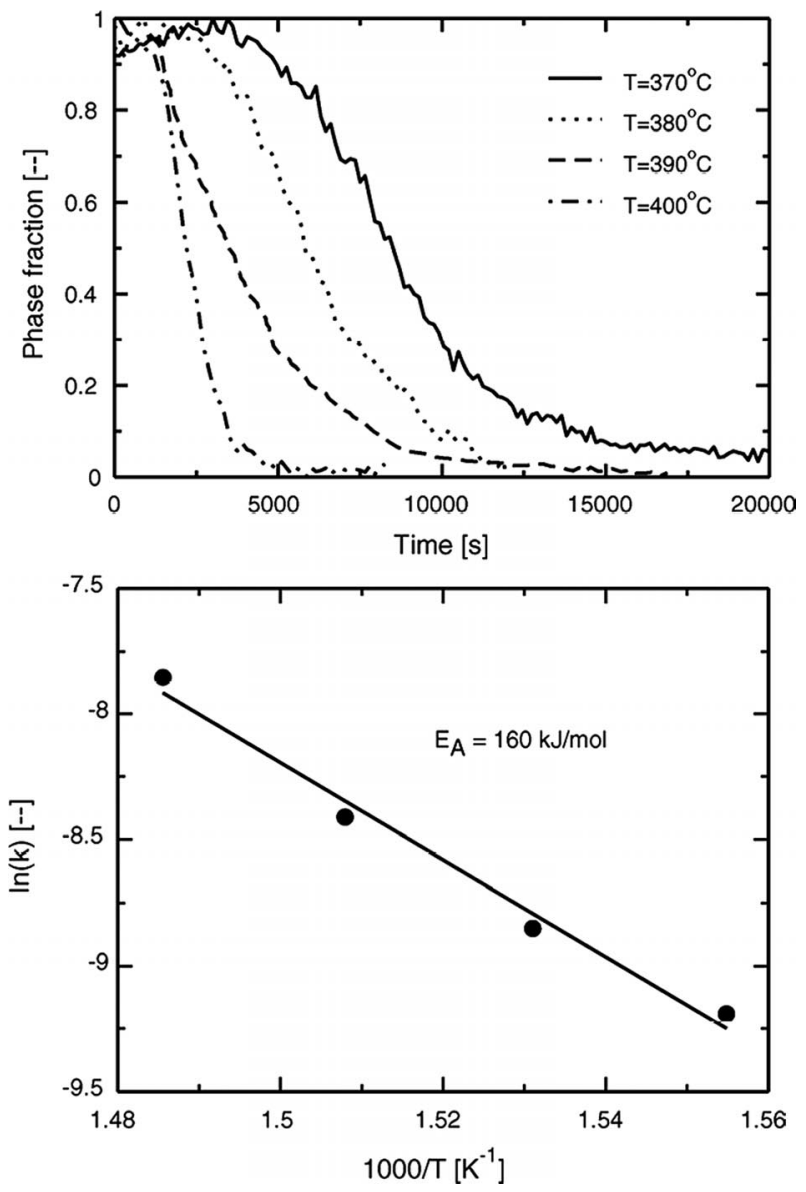

Figure 12. Upper: Experimental dehydrogenation curves of pure $\mathrm{MgH}_{2}$ in $\mathrm{MgH}_{2}-\mathrm{Al}$ determined from intensity of the $\mathrm{MgH}_{2}\left(\begin{array}{lll}1 & 1 & 0\end{array}\right)$ reflection from time resolved in situ PXD data (data collected in-house using a rotating anode, $\lambda=1.5418 \AA$ ). Lower: Arrhenius plot of $\ln k$, versus reciprocal temperature for the dehydrogenation of $\mathrm{MgH}_{2}$ Al. ${ }^{[101]}$

$k=A \cdot \exp \left(-E_{\mathrm{A}} / R T\right)$

where $A$ is a pre-exponential factor, $E_{\mathrm{A}}$ is the apparent activation energy and $R$ is the gas constant. The activation energy is denoted "apparent" since it refers to an unknown overall rate determining process and not a specific mechanism. The apparent activation energy is useful in order to compare similar reactions or the same reaction taking place at different physical conditions. 'Catalytic' effects were investigated for hydrogen release in the systems $\mathrm{MgH}_{2}, \mathrm{MgH}_{2}-\mathrm{Ni}, \mathrm{MgH}_{2}-\mathrm{Al}$ and $\mathrm{MgH}_{2}-\mathrm{Cu}$, where the apparent activation energies were extracted from in situ PXD data to be, 299, 241, 160 and $108 \mathrm{~kJ}$ $\mathrm{mol}^{-1}$, respectively. ${ }^{[98,101,102]}$

Time-resolved in situ SR-PXD has been utilized to study hydrothermal synthesis reactions of metal-substituted nanoporous aluminium phosphate (MAPO) formation. ${ }^{[103]}$ Precursor phases could be detected during formation of micro- 


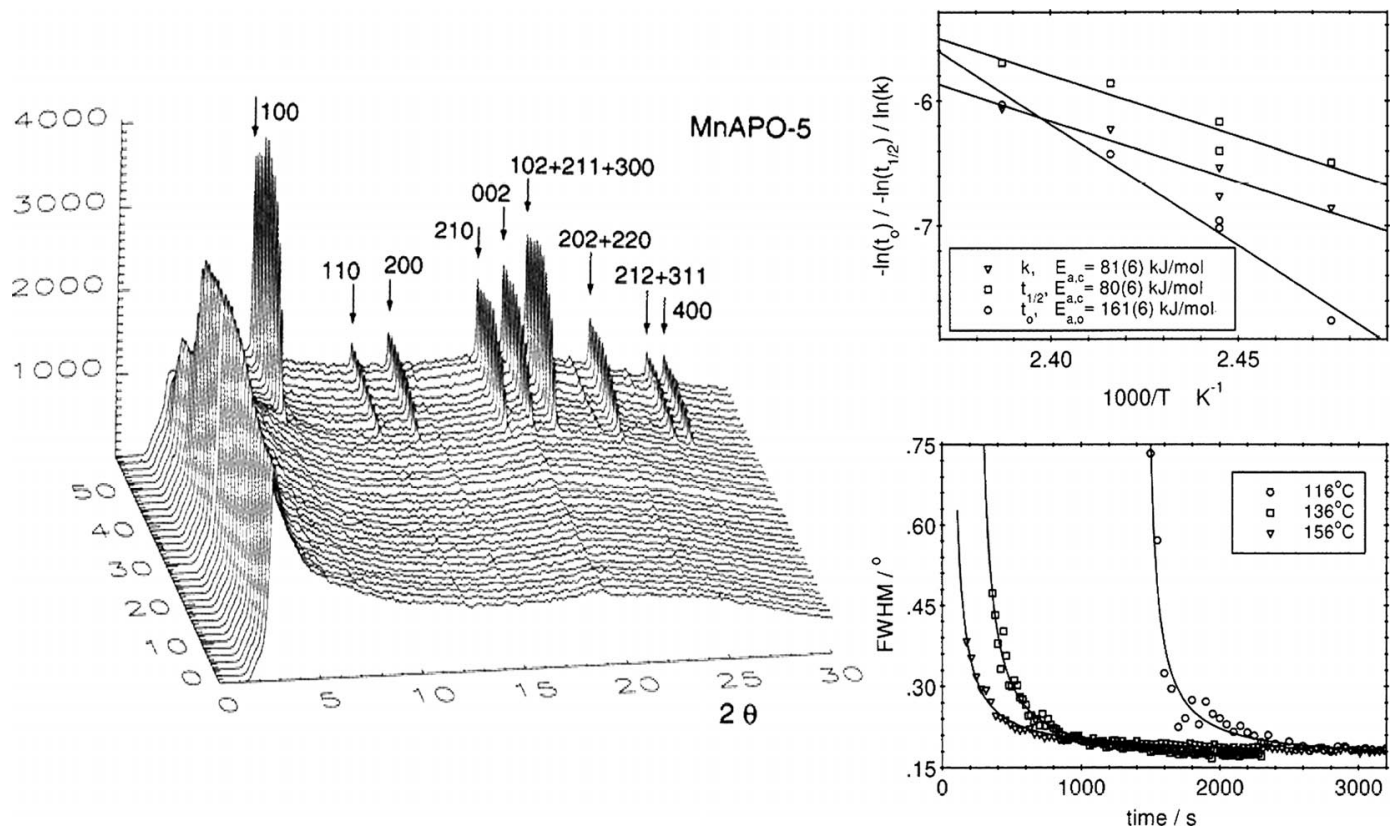

Figure 13. In situ SR-PXD patterns (left) of $\mathrm{Mn}^{2+}$-substituted aluminium phosphate, the reaction product is denoted MnAPO-5 (AFI). Arrhenius plots (upper right) for determination of activation energies for nucleation and crystallization of MnAPO-5, AFI. Note that the apparent activation energies, $E_{\mathrm{A}}$, determined using rate constants, $k$, and time for $50 \%$ conversion, $t_{1 / 2}$, are almost identical. Changes in FWHM as a function of time (lower right) for the (101) Bragg reflections of ZnAPO-47 (CHA) measured at isothermal conditions at 116 , 136, and $156{ }^{\circ} \mathrm{C} \cdot{ }^{[104]}$

porous Co-, Mg-, Mn-, and ZnMAPO's and the formation of MAPO's depends upon choice of template, substituting $\mathrm{M}^{2+}$ ion, concentrations, heating rate and reaction temperatures. In this case, the Avrami equation was fitted to the $\alpha(t)$ data sets, which in all cases gave the exponent $n=1.0$. The crystallization of MnAPO-5 (AFI) can thus be expressed by the equation $\alpha(t)=1-\exp \left(-k\left(t-t_{0}\right)\right)$, where $k$ is the rate constant and $t_{\mathrm{o}}$ is the time of the induction period or rather, the time for nucleation.

In situ SR-PXD data for the crystallisation of an aluminophosphate gel is presented in Figure 13. At low $2 \theta$ values a background matching the amorphous gel is present which increases in intensity during heating, before eventually disappearing owing to formation of initially the precursor, APO-5, and finally the product $\mathrm{AlPO}_{4}$. The change in intensity indicates ripening and nucleation upon heating the gel.

In some cases a delay time, $t_{0}$, related to a nucleation time is observed prior to the reaction and hence must be taken into account:

$\alpha(t)=\exp \left(-\left(k\left(t-t_{0}\right)\right)^{n}\right)$

An Arrhenius plot of $-\ln \left(t_{0}\right)$ vs. $1 / T$ allows determination of an apparent activation energy for the nucleation process, $E_{\mathrm{A} 0 .}{ }^{[104]}$ This approach was carried out on various aluminophosphates synthesized hydrothermally. From these fits it was possible to determine the apparent activation energy for both the nucleation and the crystallization. It was found that the apparent activation energy for nucleation is twice the value of crystallization. Additionally, the full-width-half-maximum (FWHM) was determined for a ZnAPO-47 (CHA) Bragg reflection at isothermal conditions and the changes with time assigned to particle growth (see Figure 13).

\section{9) The Crystallite Size of Nanoconfined $\mathrm{NaAlH}_{4}$}

Nanoconnement is a new bottom-up approach for stabilisation of nanoparticles in an inert nanoporous scaffold material. ${ }^{[105-112]}$ The confinement limits the particle size to the pore size of the scaffold material, which allows direct production of smaller particles than mechanically obtainable. This approach has several advantages: $(i)$ increased surface area of the reactants, (ii) nanoscale diffusion distances, and (iii) increased number of grain boundaries, which facilitate release and uptake of hydrogen and enhance reaction kinetics. ${ }^{[113-118]}$ In situ SR-PXD is an excellent method to follow reactions taking place at the nanoscale inside the scaffolds, e.g. direct synthesis of $\mathrm{MgH}_{2}$ from dibutylmagnesium. ${ }^{[95]}$ An average crystallite size may also be determined by PXD. However, to determine the exact particle size distribution small-angle X-ray scattering (SAXS) is necessary. This technique enables studies of particles in the size range from approximately 1 to $200 \mathrm{~nm}$ but yields no information on crystallinity. Several studies have proven this technique valuable within nanoscale particles. ${ }^{[119-121]}$

The amount of bulk $\mathrm{NaAlH}_{4}$ relative to nanoconfined $\mathrm{NaAlH}_{4}$ after the infiltration process can also be investigated by Rietveld refinement of PXD data. The analysis revealed that the Bragg diffraction peak shapes can be modelled as a superposition of a broad contribution from nanoconfined $\mathrm{NaAlH}_{4}$ and a narrow contribution from bulk $\mathrm{NaAlH}_{4}$ (Figure 14). ${ }^{[117]}$ This approach provides the ratio of nanoconfined versus bulk $\mathrm{NaAlH}_{4}$ as well as the average crystallite size for nanoconfined $\mathrm{NaAlH}_{4}$ and the amount of $\mathrm{Al}$ present in the sample due to decomposition of $\mathrm{NaAlH}_{4} \cdot{ }^{[117]}$ Only a minor fraction is decomposed to $\mathrm{Al}$ and a majority of the remaining 
$\mathrm{NaAlH}_{4}$ is successfully nanoconfined. The results also reveal decreasing average crystallite sizes of $\sim 19,18,17$ and $13 \mathrm{~nm}$ for nanoconfined $\mathrm{NaAlH}_{4}$ in activated scaffolds with maximum of the BET pore size distributions in the range 8 to 11 $\mathrm{nm}$. This observation indicates that $\mathrm{NaAlH}_{4}$ may preferably crystallize in the larger pores of the carbon aerogel.

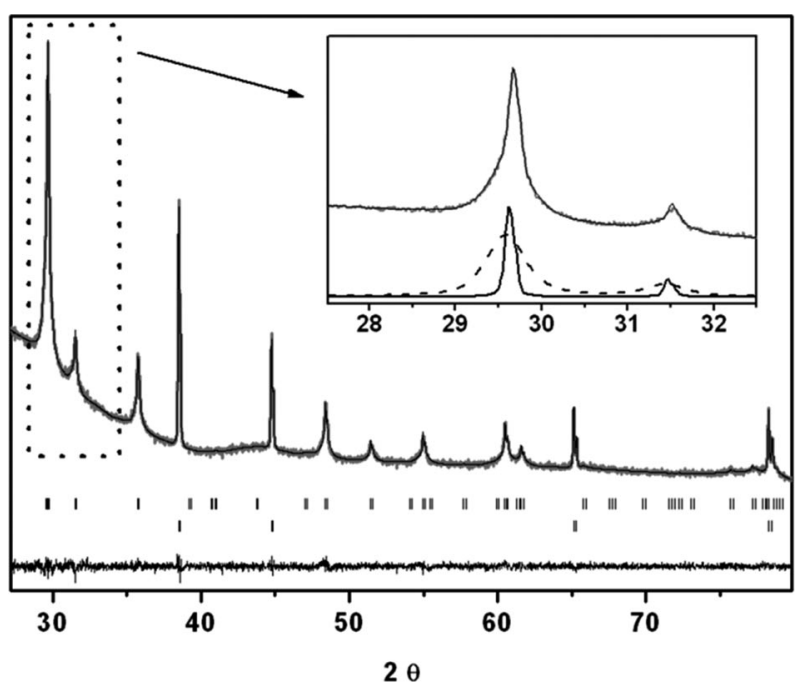

Figure 14. PXD pattern of $\mathrm{NaAlH}_{4}$ nanoconfined in nanoporus carbon aerogel activated 5 hours in a flow of $\mathrm{CO}_{2}$ (denoted CA-5.1, ${ }^{[117]} \lambda=$ $1.54 \AA, \mathrm{Cu}-K_{\alpha}$ ). The raw data curve and the calculated Rietveld model data curve fits well. The difference plot further illustrates the fit quality. Reflection markers from top to bottom show $\mathrm{NaAlH}_{4}$ and Al. The square inset shows the diffracted intensity of nanoconfined (dashed curve) and bulk (solid curve) $\mathrm{NaAlH}_{4} \cdot{ }^{[117]}$

Thus, nanoconfinement of $\mathrm{NaAlH}_{4}$ improves hydrogen release and uptake kinetics and the reversible hydrogen storage capacity. ${ }^{[110,118,122-125]}$ This hypothesis is also supported by a systematic study of the properties of $\mathrm{NaAlH}_{4}$ as a function of pore size of a carbon aerogel scaffold ranging from small nanopores $(<4 \mathrm{~nm})$ to large macropores $(>100 \mathrm{~nm}) .{ }^{[126]}$ The maximum of the pore size distribution, $D_{\max }$, was determined by standard nitrogen adsorption methods (gas sorption analysis). The full width at half-maximum, FWHM, for the Bragg diffraction peaks before and after melt infiltration was extracted from Rietveld refinements of the in situ SR-PXD data. Estimation of the average crystallite size in various scaffolds with different pore sizes was calculated from Rietveld refinement and is displayed in Figure 15, where a linear correlation between crystallite size and aerogel pore size is observed. Noteworthy is that the average crystallite size is larger than the average pore size, which further indicates that crystallization preferably takes place in the larger pores of the scaffold. ${ }^{[126]}$

\section{Conclusions}

This review paper has a focus mainly on solid-solid and solid-gas reactions, with examples from hydrogen release and uptake reactions in solids investigated by in situ synchrotron radiation powder X-ray diffraction (SR-PXD). An advanced

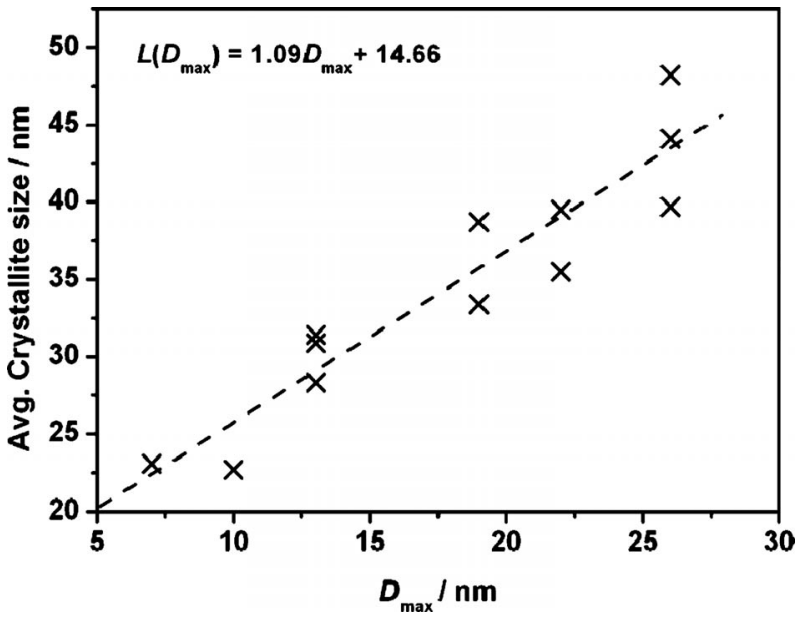

Figure 15. The average crystallite size, $L$, of nanoconfined $\mathrm{NaAlH}_{4}$ determined using SR-PXD data and plotted as a function of $D_{\max }$. Different fractions of the same sample were measured and analysed up to three times. ${ }^{[126]}$

approach denoted decomposition-aided indexing and structure solution is described, which allows structural investigation of new compounds in mixtures with other compounds using in situ SR-PXD. However, in some challenging cases SR-PXD data may be supported by neutron diffraction (PND), solidstate NMR and/or theoretical methods (DFT) in order to extract a satisfying structural model. This review demonstrates in situ SR-PXD as an excellent tool to clarify reaction pathways and discover intermediates taking part in the reaction mechanism. Furthermore, hydrogen release and uptake, polymorphic transformations, anion substitution of solid compounds etc. can be investigated in detail by sequential Rietveld refinement of SR-PXD data at variable pressures and temperatures. Additionally, physical properties such as crystallite size and apparent activation energies can be extracted. Nanoconfinement of various hydrides in nanoporous scaffolds is confirmed by Bragg peak broadening and crystallite sizes as function of pore sizes can be extracted by Rietveld refinement. These studies emphasize that in situ SR-PXD is a powerful and versatile technique crucial for many aspects of materials science. This review may provide new inspiration for design of experiments and utilization of powder X-ray diffraction.

\section{Acknowledgments}

The access to beamtime at several synchrotron facilities is gratefully acknowledged: MAX-II synchrotron, Lund, Sweden in the research laboratory MAX-Lab; PETRA III at DESY, Hamburg, Germany; The Swiss-Norwegian beam line at ESRF, Grenoble, France and Diamond light source, Oxford, UK. The work was supported by the Danish National Research Foundation, Center for Materials Crystallography (DNRF93), The Danish Council for Strategic Research (project HyFillFast), and by the Danish Research Council for Nature and Universe (Danscatt). We are grateful to the Carlsberg Foundation. We also acknowledge funding from the European Community's Seventh Framework Programme, The Fuel Cells and Hydrogen Joint Undertaking (FCH JU), project BOR4STORE (303428). Part of this work 
was supported by the COST Action MP1103 "Nanostructured materials for solid-state hydrogen storage".

\section{References}

[1] C. Liu, U. Burghaus, F. Besenbacher, Z. L. Wang, ACS Nano 2010, 4, 5517-5526.

[2] O. J. Borkiewicz, B. Shyam, K. M. Wiaderek, C. Kurtz, P. J. Chupas, K. W. Chapman, J. Appl. Crystallogr. 2012, 45, 12611269.

[3] D. B. Ravnsbæk, K. Xiang, W. Xing, O. J. Borkiewicz, K. M. Wiaderek, P. Gionet, K. W. Chapman, P. J. Chupas, Y.-M. Chiang, Nano Lett. 2014, 14, 1484-1491.

[4] K. M. Wiaderek, O. J. Borkiewicz, N. Pereira, J. Ilavsky, G. G. Amatucci, P. J. Chupas, K. W. Chapman, J. Am. Chem. Soc. 2014, 136, 6211-6214.

[5] B. S. Clausen, G. Steffensen, B. Fabius, J. Villadsen, R. Feidenhans'1, H. Topsøe, J. Catal. 1991, 132, 524-535.

[6] P. Norby, Curr. Opin. Colloid Interf. Sci. 2006, 11, 118-125.

[7] P. Norby, J. Am. Chem. Soc. 1997, 119, 5215-5221.

[8] T. R. Jensen, T. K. Nielsen, Y. Filinchuk, J.-E. Jørgensen, Y. Cerenius, E. M. Gray, C. J. Webb, J. Appl. Crystallogr. 2010, 43, $1456-1463$.

[9] C. P. Grey, F. I. Poshni, A. F. Gualtieri, P. Norby, J. C. Hanson, D. R. Corbin, J. Am. Chem. Soc. 1997, 119, 1981-1989.

[10] Y. Filinchuk, B. Richter, T. R. Jensen, V. Dmitriev, D. Chernyshov, H. Hagemann, Angew. Chem. Int. Ed. 2011, 50, 11162 11166.

[11] E. H. Kisi, E. M. Gray, S. J. Kennedy, J. Alloys Compd. 1994, 216, 123-129.

[12] T. K. Nielsen, T. R. Jensen, Int. J. Hydrog. Energy 2012, 37, 13409-13416.

[13] L. H. Jepsen, M. B. Ley, Y.-S. Lee, Y. W. Cho, M. Dornheim, J. O. Jensen, Y. Filinchuk, J. E. Jørgensen, F. Besenbacher, T. R. Jensen, Mater. Today 2014, 17, 129-135.

[14] M. B. Ley, L. H. Jepsen, Y.-S. Lee, Y. W. Cho, J. M. Bellosta von Colbe, M. Dornheim, M. Rokni, J. O. Jensen, M. Sloth, Y. Filinchuk, et al, Mater. Today 2014, 17, 122-128.

[15] E. M. Gray, D. J. Cookson, T. P. Blach, J. Appl. Crystallogr. 2006, 39, 850-855.

[16] K. M. Ø. Jensen, C. Tyrsted, M. Bremholm, B. B. Iversen, ChemSusChem 2014, 7, 1594-1611.

[17] J. Becker, M. Bremholm, C. Tyrsted, B. Pauw, K. M. Ø. Jensen, J. Eltzholt, M. Christensen, B. B. Iversen, J. Appl. Crystallogr. 2010, 43, 729-736.

[18] K. M. Ø. Jensen, M. Christensen, C. Tyrsted, M. Bremholm, B. B. Iversen, Cryst. Growth Des. 2011, 11, 753-758.

[19] A. N. Christensen, M. Olesen, Y. Cerenius, T. R. Jensen, Chem. Mater. 2008, 20, 2124-2132.

[20] A. N. Christensen, T. R. Jensen, J. C. Hanson, J. Solid State Chem. 2004, 177, 1944-1951.

[21] T. R. Jensen, A. N. Christensen, J. C. Hanson, Chem. Concr. Res. 2005, 35, 2300-2309.

[22] G. V. Jensen, M. Bremholm, N. Lock, G. R. Deen, T. R. Jensen, B. B. Iversen, M. Niederberger, J. S. Pedersen, H. Birkedal, Chem. Mater. 2010, 22, 6044-6055.

[23] M. P. Pitt, M. Paskevicius, D. H. Brown, D. A. Sheppard, C. E. Buckley, J. Am. Chem. Soc. 2013, 135, 6930-6941.

[24] D. B. Ravnsbæk, Y. Filinchuk, R. Černý, M. B. Ley, D. Haase, H. J. Jakobsen, J. Skibsted, T. R. Jensen, Inorg. Chem. 2010, 49, 3801-3809.

[25] M. B. Ley, D. B. Ravnsbæk, Y. Filinchuk, Y.-S. Lee, R. Janot, Y. W. Cho, J. Skibsted, T. R. Jensen, Chem. Mater. 2012, 24, 1654-1663.

[26] http://www.crytur.cz/.

[27] A. P. Hammersley, Eur. Synchrotron Radiat. Facil. Intern. Rep. ESRF97HA02T 1997.

[28] J. Kieffer, D. Karkoulis, J. Phys. Conf. Ser. 2013, 425, 202012.

[29] J. Kieffer, J. P. Wright, Powder Diffr. 2013, 28, S339-S350.
[30] A. P. Hammersley, S. O. Svensson, M. Hanfland, A. N. Fitch, D. Hausermann, High Press. Res. 1996, 14, 235-248.

[31] P. J. Chupas, K. W. Chapman, C. Kurtz, J. C. Hanson, P. L. Lee, C. P. Grey, J. Appl. Crystallogr. 2008, 41, 822-824.

[32] J. A. Rodriguez, J. C. Hanson, A. I. Frenkel, J. Y. Kim, M. Pérez, J. Am. Chem. Soc. 2002, 124, 346-354.

[33] P. J. Chupas, M. F. Ciraolo, J. C. Hanson, C. P. Grey, J. Am. Chem. Soc. 2001, 123, 1694-1702.

[34] G. W. Stinton, J. S. O. Evans, J. Appl. Crystallogr. 2007, 40, 8795.

[35] K. J. Gross, R. K. Carrington, S. Barcelo, A. Karkamkar, J. Purewal, P. Parilla, Recommended Best Practices for the Characterization of Storage Properties of Hydrogen Storage Materials, US DOE Fuel Cell Technol. Program 2009.

[36] T. E. Price, D. M. Grant, D. Weston, T. Hansen, L. M. Arnbjerg, D. B. Ravnsbæk, T. R. Jensen, G. S. Walker, J. Am. Chem. Soc. 2011, 133, 13534-13538.

[37] D. B. Ravnsbæk, Y. Filinchuk, R. Cerný, T. R. Jensen, Z. Krisallogr. 2010, 225, 557-569.

[38] L. H. Rude, T. K. Nielsen, D. B. Ravnsbæk, U. Bösenberg, M. B. Ley, B. Richter, L. M. Arnbjerg, M. Dornheim, Y. Filinchuk, F. Besenbacher, et al, Phys. Status Solidi A 2011, 208, 1754-1773.

[39] J. Huot, D. B. Ravnsbæk, J. Zhang, F. Cuevas, M. Latroche, T. R. Jensen, Prog. Mater. Sci. 2013, 58, 30-75.

[40] D. B. Ravnsbæk, L. H. Sørensen, Y. Filinchuk, F. Besenbacher, T. R. Jensen, Angew. Chem. Int. Ed. 2012, 51, 3582-3586.

[41] C. Pistidda, E. Napolitano, D. Pottmaier, M. Dornheim, T. Klassen, M. Baricco, S. Enzo, Int. J. Hydrog. Energy 2013, 38, 10479-10484.

[42] R. Cerný, Z. Kristallogr. 2008, 223, 607-616.

[43] J. E. Olsen, C. Frommen, T. R. Jensen, M. D. Riktor, M. H. Sørby, B. C. Hauback, RSC Adv. 2013, 4, 1570-1582.

[44] C. Frommen, M. H. Sørby, P. Ravindran, P. Vajeeston, H. Fjellvåg, B. C. Hauback, J. Phys. Chem. C 2011, 115, 2359123602.

[45] J. E. Olsen, C. Frommen, M. H. Sørby, B. C. Hauback, RSC Adv. 2013, 3, 10764-10774.

[46] A. V. Skripov, A. V. Soloninin, M. B. Ley, T. R. Jensen, Y. Filinchuk, J. Phys. Chem. C 2013, 117, 14965-14972.

[47] M. B. Ley, S. Boulineau, R. Janot, Y. Filinchuk, T. R. Jensen, J. Phys. Chem. C 2012, 116, 21267-21276.

[48] R. Černý, P. Schouwink, Y. Sadikin, K. Stare, L. Smrčok, B. Richter, T. R. Jensen, Inorg. Chem. 2013, 52, 9941-9947.

[49] D. B. Ravnsbæk, E. A. Nickels, R. Černý, C. H. Olesen, W. I. F. David, P. P. Edwards, Y. Filinchuk, T. R. Jensen, Inorg. Chem. 2013, 52, 10877-10885.

[50] P. Schouwink, M. B. Ley, T. R. Jensen, R. Černý, Dalton Trans. 2014, 7726-7733.

[51] P. Schouwink, V. D’Anna, M. B. Ley, L. M. Lawson Daku, B. Richter, T. R. Jensen, H. Hagemann, R. Černý, J. Phys. Chem. C 2012, 116, 10829-10840.

[52] D. Ravnsbæk, Y. Filinchuk, Y. Cerenius, H. J. Jakobsen, F. Besenbacher, J. Skibsted, T. R. Jensen, Angew. Chem. Int. Ed. 2009, $48,121,6787-6791$.

[53] M. Dornheim, N. Eigen, G. Barkhordarian, T. Klassen, R. Bormann, Adv. Eng. Mater. 2006, 8, 377-385.

[54] P. Chen, Z. Xiong, J. Luo, J. Lin, K. L. Tan, Nature 2002, 420, 302-304.

[55] G. Barkhordarian, T. Klassen, M. Dornheim, R. Bormann, J. Alloys Compd. 2007, 440, L18-L21.

[56] J. J. Vajo, F. Mertens, C. C. Ahn, R. C. Bowman, B. Fultz, J. Phys. Chem. B 2004, 108, 13977-13983.

[57] J. J. Vajo, G. L. Olson, Scr. Mater. 2007, 56, 829-834.

[58] Y. W. Cho, J.-H. Shim, B.-J. Lee, CALPHAD Comput. Coupling Phase Diagrams Thermochem. 2006, 30, 65-69.

[59] K.-B. Kim, J.-H. Shim, Y. W. Cho, K. H. Oh, Chem. Commun. 2011, 47, 9831-9833.

[60] D. M. Liu, W. J. Huang, T. Z. Si, Q. A. Zhang, J. Alloys Compd. 2013, 551, 8-11. 
[61] U. Bösenberg, S. Doppiu, L. Mosegaard, G. Barkhordarian, N. Eigen, A. Borgschulte, T. R. Jensen, Y. Cerenius, O. Gutfleisch, T. Klassen, et al, Acta Mater. 2007, 55, 3951-3958.

[62] U. Bösenberg, J. W. Kim, D. Gosslar, N. Eigen, T. R. Jensen, J. M. B. von Colbe, Y. Zhou, M. Dahms, D. H. Kim, R. Günther, et al, Acta Mater. 2010, 58, 3381-3389.

[63] U. Bösenberg, D. B. Ravnsbæk, H. Hagemann, V. D’ Anna, C. B. Minella, C. Pistidda, W. van Beek, T. R. Jensen, R. Bormann, M. Dornheim, J. Phys. Chem. C 2010, 114, 15212-15217.

[64] O. Friedrichs, J. W. Kim, A. Remhof, F. Buchter, A. Borgschulte, D. Wallacher, Y. W. Cho, M. Fichtner, K. H. Oh, A. Züttel, Phys. Chem. Chem. Phys. 2009, 11, 1515-1520.

[65] B. R. S. Hansen, D. B. Ravnsbæk, J. Skibsted, T. R. Jensen, Phys. Chem. Chem. Phys. 2014, 16, 8970-8980.

[66] D. B. Ravnsbæk, T. R. Jensen, J. Appl. Phys. 2012, 111, 112621.

[67] D. B. Ravnsbæk, T. R. Jensen, J. Phys. Chem. Solids 2010, 71, 1144-1149.

[68] L. H. Jepsen, D. B. Ravnsbæk, C. Grundlach, F. Besenbacher, J. Skibsted, T. R. Jensen, Dalton Trans. 2014, 43, 3095-3103.

[69] L. H. Rude, O. Zavorotynska, L. M. Arnbjerg, D. B. Ravnsbæk, R. A. Malmkjær, H. Grove, B. C. Hauback, M. Baricco, Y. Filinchuk, F. Besenbacher, et al, Int. J. Hydrog. Energy 2011, 36, 15664-15672.

[70] L. H. Rude, E. Groppo, L. M. Arnbjerg, D. B. Ravnsbæk, R. A. Malmkjær, Y. Filinchuk, M. Baricco, F. Besenbacher, T. R. Jensen, J. Alloys Compd. 2011, 509, 8299-8305.

[71] D. B. Ravnsbæk, L. H. Rude, T. R. Jensen, J. Solid State Chem. 2011, 184, 1858-1866.

[72] I. Llamas-Jansa, N. Aliouane, S. Deledda, J. E. Fonneløp, C. Frommen, T. Humphries, K. Lieutenant, S. Sartori, M. H. Sørby, B. C. Hauback, J. Alloys Compd. 2012, 530, 186-192.

[73] T. Matsunaga, F. Buchter, P. Mauron, M. Bielman, Y. Nakamori, S. Orimo, N. Ohba, K. Miwa, S. Towata, A. Züttel, J. Alloys Compd. 2008, 459, 583-588.

[74] G. L. Soloveichik, Y. Gao, J. Rijssenbeek, M. Andrus, S. Kniajanski, R. C. Bowman Jr., S.-J. Hwang, J.-C. Zhao, Int. J. Hydrog. Energy 2009, 34, 916-928.

[75] P. Zanella, L. Crociani, N. Masciocchi, G. Giunchi, Inorg. Chem. 2007, 46, 9039-9041.

[76] C. Pistidda, S. Garroni, F. Dolci, E. G. Bardají, A. Khandelwal, P. Nolis, M. Dornheim, R. Gosalawit, T. Jensen, Y. Cerenius, et al, J. Alloys Compd. 2010, 508, 212-215.

[77] G. Severa, E. Rönnebro, C. M. Jensen, Chem. Commun. 2010, 46, 421-423.

[78] W. I. F. David, S. K. Callear, M. O. Jones, P. C. Aeberhard, S. D. Culligan, A. H. Pohl, S. R. Johnson, K. R. Ryan, J. E. Parker, P. P. Edwards, et al, Phys. Chem. Chem. Phys. 2012, 14, 1180011807.

[79] M. Paskevicius, M. P. Pitt, C. J. Webb, D. A. Sheppard, U. Fils $\emptyset$, E. M. Gray, C. E. Buckley, J. Phys. Chem. C 2012, 116, 1523115240.

[80] A. Amieiro-Fonseca, S. R. Ellis, C. J. Nuttall, B. E. Hayden, S. Guerin, G. Purdy, J.-P. Soulié, S. K. Callear, S. D. Culligan, W. I. F. David, et al, J. Chem. Soc., Faraday Trans. 2011, 151, 369.

[81] Y. Filinchuk, R. Černý, H. Hagemann, Chem. Mater. 2009, 21, 925-933.

[82] J.-H. Her, P. W. Stephens, Y. Gao, G. L. Soloveichik, J. Rijssenbeek, M. Andrus, J.-C. Zhao, Acta Crystallogr., Sect. B 2007, $63,561-568$.

[83] R. J. Newhouse, V. Stavila, S.-J. Hwang, L. E. Klebanoff, J. Z. Zhang, J. Phys. Chem. C 2010, 114, 5224-5232.

[84] N. P. Stadie, E. Callini, B. Richter, T. R. Jensen, A. Borgschulte, A. Züttel, J. Am. Chem. Soc. 2014, 136, 8181-8184.

[85] M. Hirscher, B. Panella, Scr. Mater. 2007, 56, 809-812.

[86] B. Panella, M. Hirscher, Adv. Mater. 2005, 17, 538-541.

[87] K.-F. Aguey-Zinsou, T. Nicolaisen, J. R. Ares Fernandez, T. Klassen, R. Bormann, J. Alloys Compd. 2007, 434-435, 738742.
[88] W. Oelerich, T. Klassen, R. Bormann, J. Alloys Compd. 2001, $315,237-242$.

[89] A. Zaluska, L. Zaluski, J. O. Ström-Olsen, J. Alloys Compd. 1999, 288, 217-225.

[90] G. Barkhordarian, T. Klassen, R. Bormann, J. Phys. Chem. B 2006, 110, 11020-11024.

[91] G. Barkhordarian, T. Klassen, R. Bormann, J. Alloys Compd. 2004, 364, 242-246.

[92] M. Paskevicius, D. A. Sheppard, C. E. Buckley, J. Am. Chem. Soc. 2010, 132, 5077-5083.

[93] Z. Zhao-Karger, J. Hu, A. Roth, D. Wang, C. Kübel, W. Lohstroh, M. Fichtner, Chem. Commun. 2010, 46, 8353-8355.

[94] C. Zlotea, M. Sahlberg, S. Özbilen, P. Moretto, Y. Andersson, Acta Mater. 2008, 56, 2421-2428.

[95] T. K. Nielsen, K. Manickam, M. Hirscher, F. Besenbacher, T. R. Jensen, ACS Nano 2009, 3, 3521-3528.

[96] O. Friedrichs, J. C. Sánchez-López, C. López-Cartes, T. Klassen, R. Bormann, A. Fernández, J. Phys. Chem. B 2006, 110, 78457850 .

[97] L. Z. Vegard, Phys. Hadrons Nucl. 1921, 5, 17 -26.

[98] T. R. Jensen, A. Andreasen, T. Vegge, J. W. Andreasen, K. Ståhl, A. S. Pedersen, M. M. Nielsen, A. M. Molenbroek, F. Besenbacher, Int. J. Hydrog. Energy 2006, 31, 2052-2062.

[99] A. Karty, J. Grunzweig-Genossar, P. S. Rudman, J. Appl. Phys. 1979, 50, 7200-7209.

[100] C. M. Stander, J. Inorg. Nucl. Chem. 1977, 39, 221-223.

[101] A. Andreasen, M. B. Sørensen, R. Burkarl, B. Møller, A. M. Molenbroek, A. S. Pedersen, J. W. Andreasen, M. M. Nielsen, T. R. Jensen, J. Alloys Compd. 2005, 404-406, 323-326.

[102] A. Andreasen, M. B. Sørensen, R. Burkarl, B. Møller, A. M. Molenbroek, A. S. Pedersen, T. Vegge, T. R. Jensen, Appl. Phys. A 2006, 82, 515-521.

[103] P. Norby, Mater. Sci. Forum 1996, 228-231, 147-152.

[104] A. N. Christensen, T. R. Jensen, P. Norby, J. C. Hanson, Chem. Mater. 1998, 10, 1688-1693.

[105] A. F. Gross, J. J. Vajo, S. L. Van Atta, G. L. Olson, J. Phys. Chem. C 2008, 112, 5651-5657.

[106] A. Gutowska, L. Li, Y. Shin, C. M. Wang, X. S. Li, J. C. Linehan, R. S. Smith, B. D. Kay, B. Schmid, W. Shaw, et al, Angew. Chem. Int. Ed. 2005, 44, 3578-3582.

[107] H. Kim, A. Karkamkar, T. Autrey, P. Chupas, T. Proffen, J. Am. Chem. Soc. 2009, 131, 13749-13755.

[108] S. Sartori, K. D. Knudsen, Z. Zhao-Karger, E. G. Bardaij, M. Fichtner, B. C. Hauback, Nanotechnology 2009, 20, 505702.

[109] C. P. Baldé, B. P. C. Hereijgers, J. H. Bitter, K. P. de Jong, Angew. Chem. Int. Ed. 2006, 45, 3501-3503.

[110] T. K. Nielsen, U. Bösenberg, R. Gosalawit, M. Dornheim, Y. Cerenius, F. Besenbacher, T. R. Jensen, ACS Nano 2010, 4, 3903-3908.

[111] R. Gosalawit-Utke, C. Milanese, P. Javadian, J. Jepsen, D. Laipple, F. Karmi, J. Puszkiel, T. R. Jensen, A. Marini, T. Klassen, et al, Int. J. Hydrog. Energy 2013, 38, 3275-3282.

[112] R. Gosalawit-Utke, C. Milanese, T. K. Nielsen, F. Karimi, I. Saldan, K. Pranzas, T. R. Jensen, A. Marini, T. Klassen, M. Dornheim, Int. J. Hydrog. Energy 2013, 38, 1932-1942.

[113] F. E. Pinkerton, J. Alloys Compd. 2011, 509, 8958-8964

[114] J. J. Vajo, Curr. Opin. Solid State Mater. Sci. 2011, 16, 15, 5261.

[115] M. Fichtner, Nanotechnology 2009, 20, 204009.

[116] P. E. de Jongh, P. Adelhelm, ChemSusChem 2010, 3, 1332-1348.

[117] T. K. Nielsen, P. Javadian, M. Polanski, F. Besenbacher, J. Bystrzycki, J. Skibsted, T. R. Jensen, Nanoscale 2014, 6, 599607.

[118] T. K. Nielsen, F. Besenbacher, T. R. Jensen, Nanoscale 2011, 3, 2086-2098.

[119] H. Y. Tian, C. E. Buckley, S. Mulè, M. Paskevicius, B. B. Dhal, Nanotechnology 2008, 19, 475605.

[120] M. Paskevicius, H.-Y. Tian, D. A. Sheppard, C. J. Webb, M. P. Pitt, E. M. Gray, N. M. Kirby, C. E. Buckley, J. Phys. Chem. C 2011, 115, 1757-1766. 
[121] M. Paskevicius, J. Webb, M. P. Pitt, T. P. Blach, B. C. Hauback, E. Gray, C. E. Buckley, J. Alloys Compd. 2009, 481, 595-599.

[122] J. Gao, P. Adelhelm, M. H. W. Verkuijlen, C. Rongeat, M. Herrich, P. J. M. van Bentum, O. Gutfleisch, A. P. M. Kentgens, K. P. de Jong, P. E. de Jongh, J. Phys. Chem. C 2010, 114, 46754682.

[123] R. D. Stephens, A. F. Gross, S. L. V. Atta, J. J. Vajo, F. E. Pinkerton, Nanotechnology 2009, 20, 204018.
[124] W. Lohstroh, A. Roth, H. Hahn, M. Fichtner, ChemPhysChem 2010, 11, 789-792.

[125] S. Sartori, K. D. Knudsen, A. Roth, M. Fichtner, B. C. Hauback, Nanosci. Nanotechnol. Lett. 2012, 4, 173-177.

[126] T. K. Nielsen, P. Javadian, M. Polanski, F. Besenbacher, J. Bystrzycki, T. R. Jensen, J. Phys. Chem. C 2012, 116, 2104621051

Received: May 27, 2014 Published Online: September 12, 2014 